\title{
Action Research The first steps to start up a pilot experience in heritage education
}

\author{
Working paper
}

Janine Sprünker (jsprunker@uoc.edu)

IN3-UOC PhD research intern

\section{Working Paper Series WP08-006}

Research group: Museologia, museografia, TIC i patrimoni. MUSEIA

Research group coordinator: Glòria Munilla Cabrillana (UOC)

\section{$\bullet$ UOC}

\section{IN3 Internet

www.uoc.edu 
Internet Interdisciplinary Institute (IN3)

http://www.uoc.edu/in3

Parc Mediterrani de la Tecnologia

Av. Canal Olímpic, s/n.

08860 Castelldefels

Barcelona (Espanya)

Tel. 936735000

Universitat Oberta de Catalunya (UOC)

http://www.uoc.edu/

Av. Tibidabo, 39-43

08035 Barcelona

Espanya

Tel. 932532300 


\section{Table of Contents}

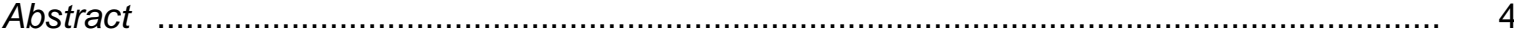

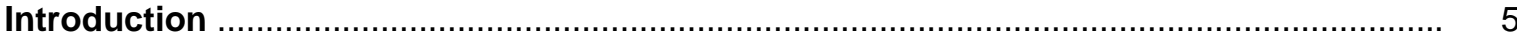

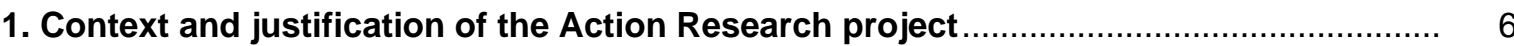

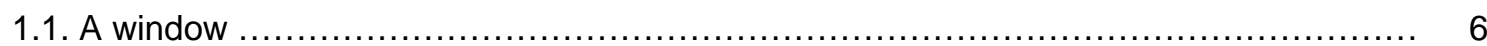

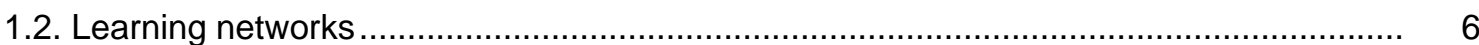

1.3. Educational online Resources with Cultural Heritage Content ................................ 7

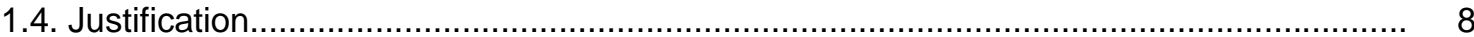

2. Action Research core concepts linked to the research project ............................ 10

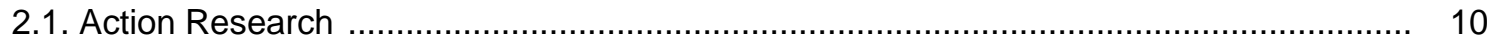

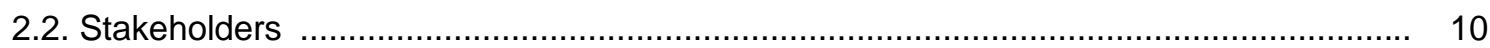

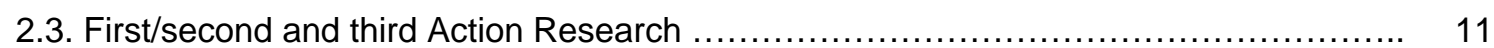

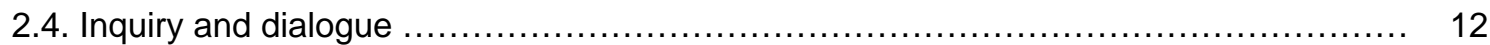

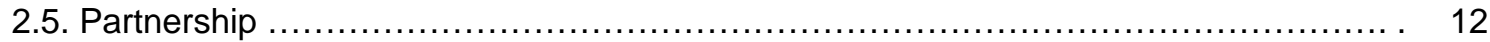

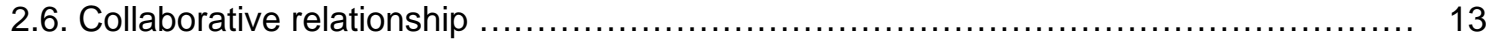

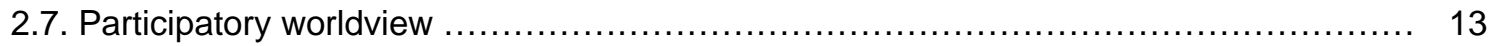

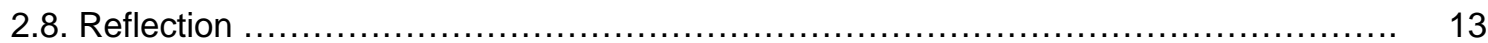

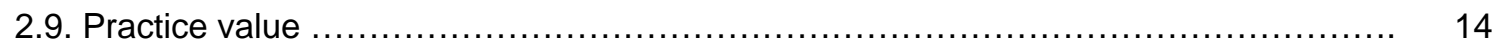

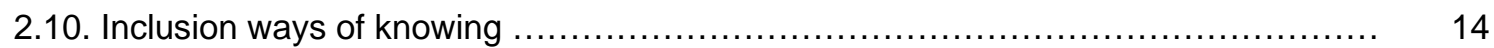

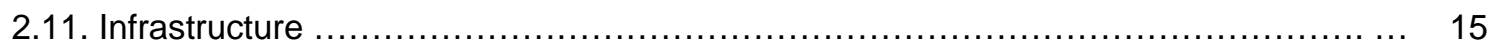

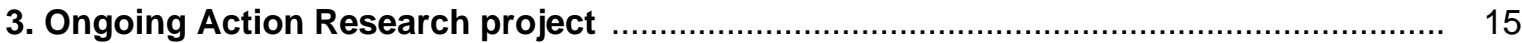

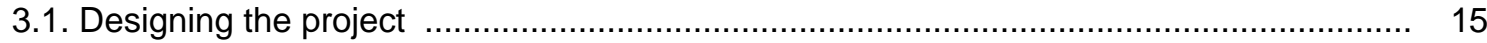

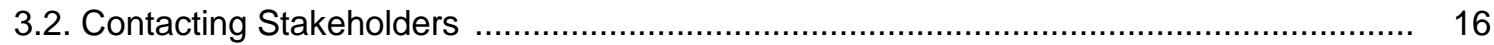

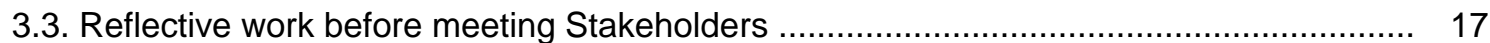

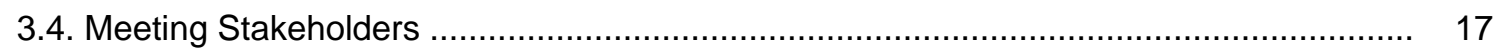

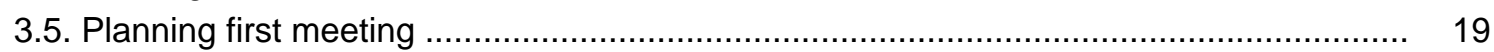

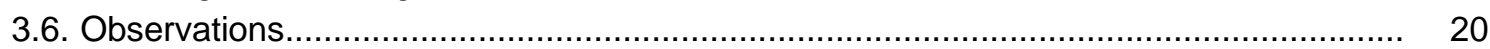

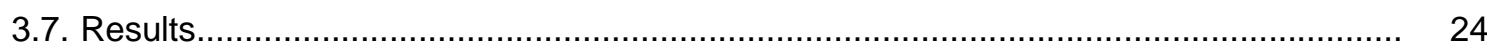

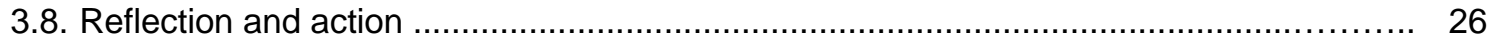

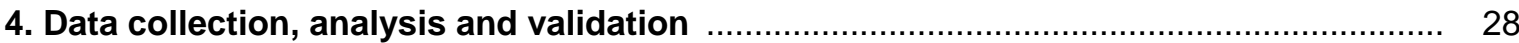

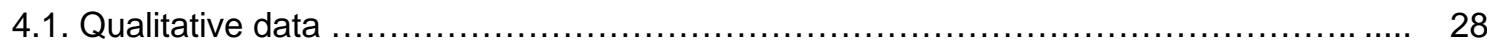

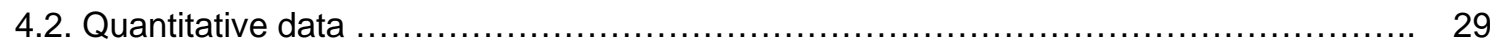

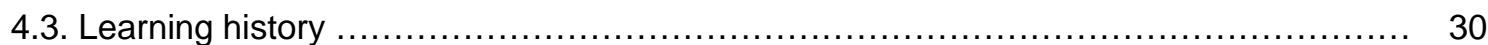

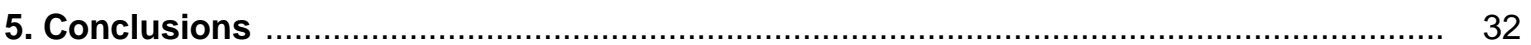

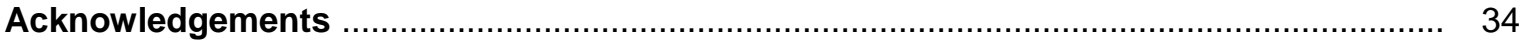

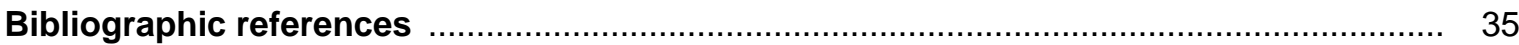

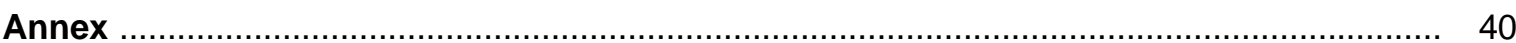




\title{
Action Research The first steps to start up a pilot experience in heritage education
}

\section{Janine Sprünker (jsprunker@uoc.edu)}

IN3-UOC PhD research intern

\begin{abstract}
The relationships museums-schools are changing through the use of Internet. We want to analyses how these new relationships occur at a national level. It is relevant to analyze these possible new relationships, product of social and technological changes which allow new interactions and participation that at the same time imply changes in organization forms, web resources management and teaching and learning models.
\end{abstract}

Concretely, shaping learning networks can establish a new form of relationship museums-schools and educational online resources with cultural heritage content can become learning opportunities and knowledge resources outside formal education walls. But there must be experimental projects to test this evidences and to seek how this kind of teaching and learning practices will work within a concrete social and cultural context. Thereby, Action Research can contribute to the development of a learning experience, based on reflection and actions.

The goal of this experimentation is to obtain a working model and good learning and teaching practices of learning networks shaped by heritage managers, teachers and students where the members will produce and use educational online resources with cultural heritage content. The outcomes of this empirical research project will be compared with results from the first methodological part of the $\mathrm{PhD}$ thesis for obtaining an exportable model to other settings.

\section{Keywords}

action research, heritage education, educational online resources, cultural heritage content, learning networks, teachers, heritage managers, high School students, researchers, learning

\section{Recommended citation:}

SPRÜNKER, Janine (2008). Action Research. The first steps to start up a pilot experience in heritage education. [online working paper]. UOC. (Working Paper Series; WP08-006). [Accessed: dd/mm/yy]. $<$ http://www.uoc.edu/in3/dt/eng/wp08006 sprunker.pdf> 


\section{Introduction}

The development of ICT allows collaborative learning and working in network and spread out new educational possibilities and new interaction channels between museums and schools. The jointly production and use of educational online resources with cultural heritage content through learning networks could contribute High School students acquiring scientific knowledge and assuming curriculum issues.

Currently, we don't find such kind of experiences at a Catalan level form which we can extract a possible working model and learning and teaching practices in heritage education or education through heritage using Internet within formal education. So, I have proposed to put forward a study and, specifically an action research which implies a pilot experience. I have engaged heritage institutions and formal education institutions for the experimentation. We will work, learn and research together. I chose to take an Action Research approach because organizational development oriented by Action Research can contribute to the fostering of the heritage education or education through heritage using Internet by facilitating dialogue spaces that allow for a multiplicity of perspectives.

The agenda of the action research approach is guided by specific objectives to analyse and understand three learning networks of heritage managers, teachers and students from different geographic settings of Catalonia and how internet-based tools and application, can be used to facilitate relationship or partnership between heritage managers, teachers and students for the use and produce of educational online resources with cultural heritage content. The study looks at the process of building and using of educational online resources with cultural heritage content through learning networks established at a virtual platform which can enable a virtual community or community of practices. This action research or network action research (Foth, 2006) uses technology to network participants and stakeholders.

Concretely, this working paper works on the second methodological part development of the PhD Thesis. It will provide an insight in Action Research through defining core concepts linked to the empirical research project, show the first step in triggering an Action Research project which is part of the second methodological part of a PhD Thesis project and emphasize the relevance of the researcher learning process and outcomes that will support the research immersed in ongoing spiral cycles of action and reflection. Action Research establishes action and reflection in a continuously and successively way. 


\section{Context and justification of the Action Research project}

This Action research included in the dissertation and the future conclusion formulations will fall within an environment where we will find an intersection of theories suitable for interdisciplinary framework. Mainly, we come across intersection of ICT, education and cultural heritage theories and practices.

The following mix of brief literature framework and empirical evidences at national and international level has guided the Action Research project and partly the Dissertation proposal. These empirical evidences must be compared with the action research outcomes while the literature must be reviewed and developed continuously. In fact, the literature drawn on for the study will develop as the researcher grows into a deeper understanding of the issues under study.

\subsection{A window}

The formal, non-formal and informal learning (Alderoqui \& Alderoqui, 1996; Asensio \& Pol, 2002; Hein, 1998; Hooper-Greenhill, 1999) borders are almost invisible by the introduction of digital content through the use of ICT in the classroom. Nowadays, we can find learning opportunities and knowledge resources outside formal education walls which could be an answer to current teaching and learning needs. In fact, the papers of the internationals conference of Museum \& The Web ${ }^{1}$ show experiences where it is emphasized that there are an increasing demand from teachers to heritage institutions. Teachers seek and add online educational resources with cultural heritage content into teaching and learning processes (Horwitz \& Intemann, 2007).

Museums present e-learning materials and activities and they also offer the option for the visitor to participate in the creation of knowledge ${ }^{2}$ through the web. So, they establish new or additional connection with the visitor and support his social and intellectual inclusion (Hein, 1998; Falk \& Dierking, 2000). Nowadays, museums, specially the museums of Anglo-Saxon tradition, look for establishing a constructive dialogue in their activities of learning, i.e. they seek to make students participant, by establishing connection netween curriculum, learning from and about objects, offer strategies for discovering information in front of obtaining direct information (Hein, 1998). The possibility of different ways of heritage interpretation offers a different kind of people access to knowledge, reaffirming the vital role of heritage institutions in our society. The museum is now a closer place to the community and it is a place more participative as much at a physical as a virtual level.

\subsection{Learning networks}

At present, teachers are exploring new forms of education practices which, for example, could facilitate the connection and organization of relevant resources in Internet. For instance, the students in learning networks could study and send messages to experts about a concrete learning subject. They could also have access to key information. The use of network services, datebases and libraries that help to access information about specifics subjects are resources greatly value in learning networks. In addition, it increases the opportunities of group work and could provide a

\footnotetext{
${ }^{1} \mathrm{http}: / / \mathrm{www}$.archimuse.com/conferences/mw.html

2 http://www.movinghere.org.uk/help/default.htm
} 
convenient interaction with their classmates linked with the course or social relationship (Harasim, 2000).

The collaboration between heritage institutions and schools has established new pedagogical methods and it can support other forms of learning, such as e-learning (UNESCO, 2006). We find different experiences of this kind of collaboration where the dimensions and the results have been different. For example, American for Arts has promoted the "Arts for At-Risk Youth" ${ }^{3}$ program; "Arts Facts...Improved Academic Performance" ${ }^{4}$ shows that the students who participate in art activities in school or out-of-school activities increase their academic achievement and the drop out rate of school leaving; the book Critical Links ${ }^{5}$ published by The Arts Education Partnership presents 62 academic research studies which show that art education increase the essential academic skills of reading and language and writing development; "Keys to imagination ICT in art education" ${ }^{6}$ is a case study of UK which concluded that it is fundamental to have technological and human equipment. Nowadays, teachers and heritage managers have to have ICT skills with social interaction capacity and technical equipment for developing education in art or art education through art.

Catalan teachers have begun to establish learning networks. But, according to the report of Projecte d'Internet Catalunya (PIC) "L'escola a la societat xarxa: Internet a l'educació primària i secundària"7 , L'escola a la societat xarxa: Internet a l'educació primària $i$ secundària (PIC d'Escoles), working in network (27\%) and communication (30.2\%) are the less frequent use of Internet while information searching $(74,7 \%)$ and exercises and simulations $(31.2 \%)$ are the more frequent activities in classrooms. However, the aim of the use of the Internet in classroom is different depending on the location of the center, specially if it is a rural school. The majority of teachers use Internet to prepare their classes. The teachers of primary education $(89,1 \%)$ are more open than the secondary teachers of ESO $(48,1 \%)$ to participate during their professional activity in the school, for example, in educational experiences together with other institutions or professionals from outside the school. Teachers of state schools have a more opener position than teachers of private centers which have a more closed practice through collaborations and participation. Relating to teaching style, in the primary education $(75.3 \%$ in front of $15.7 \%$ secondary education), we find a more student focused teaching, i.e. a more personalized teaching and participation of the student in its learning process.

\subsection{Educational Online Resources with Cultural Heritage Content}

We divide online educational resources with cultural heritage content into activities and materials in Internet. They are created by taking as a thematic axis cultural heritage. The cultural heritage could be material ${ }^{8}$ or intangible ${ }^{9}$. These kind of educational resources seek the personal development and socialization of the social and cultural environment of our students. These educational resources have the goal to develop student knowledge and skills required for living in our society. They also seek to bring closer and sensitize students about the local, social and cultural reality placed in a global framework.

\footnotetext{
${ }^{3} \mathrm{http}: / / \mathrm{www}$.americansforthearts.org/public awareness/resources/artsed publications/006.asp

${ }^{4}$ http://www.artsusa.org/pdf/get involved/advocacy/research/2007/artseducation.pdf

5 http://www.newhorizons.org/strategies/arts/catterall.htm

6 http://www.drumcroon.org.uk/newmedia/documents/Keys.pdf

7 http://www.uoc.edu/in3/pic/cat/pdf/pic escola volum1.pdf

8 http://whc.unesco.org/archive/convention-en.pdf

9 http://www.unesco.beniculturali.it/index.php?en/37/definition-of-intangible-cultural-heritage
} 
At an international level, we have web pages of museums where we find products and services linked to education; such as online libraries, discussion groups, simulations and interactions with models, games, etc. In July 1994, the "National History Museum"10 was the first museum of UK which offered on the web educational resources. In these first years of the century, online activities and materials have experimented a quick and wide increase. For example, there is the web page "24 Hours Museum" ${ }^{11}$ where there is the section "Show me"12. "Show me" was created for teachers or educators and it offers online interactivity tools of UK museums and galleries for children between 4 and 11 years.

In Catalonia, we have few examples of museum webpages which give access to educational resources. These cases don't present specific learning goals or they treat open leaning goals (Alderoqui i Alderoqui, 1996; Asensio i Pol, 2002). For example, Museu de Gavà ${ }^{13}$, Fàbrica Roca Umbert $^{14}$, Museu de la Ciència i la Tècnica de Catalunya ${ }^{15}$ and Pedrera Educació ${ }^{16}$. However, we highlight the didactic units of Maleta Pedagògica virtual de la Pesca ${ }^{17}$ of Museu de la Pesca de Catalunya. On the other hand, we have an important number of online educational resources with cultural heritage content at Xarxa Telemàtica de Catalunya ${ }^{18}$. I have gathered more than 400 online educational resources with cultural heritage content in Catalan language and from the social and art curriculum of High School students (December 2007). We divide these resources into videos $^{19}$, Clics o JClics ${ }^{20}$, Quaderns virtuals ${ }^{21}$, Webquests ${ }^{22}$, podcasts ${ }^{23}$ and interactivites Mini Unitats Didàctiques of Edu365 ${ }^{24}$. The designers are mainly teachers. They take cultural heritage as a thematic axis and develop the contents which are linked to specific learning goals. The teachers use open and social software which are tools that don't require prior or much ICT skills. These kind of software do not require a big money investment. Teacher could create own resources and, at the same time, they easily learn to use ICT.

\subsection{Justification}

Nowadays, we can find and access learning networks (Harasim, 2000) related to cultural heritage or museum networks (Iwazaki, Yasuda, Yokoi, \& Okamoto, 2002). There are museum online communities (Caruth \& Bernstein, 2007) and learning networks shaped by people who belong to cultural heritage institutions and formal education institutions. They come together in a virtual environment (Adsit, Barger, Helal \& Royal, 2007) for sharing knowledge, collaborating in projects and learning. The relationship museums-schools are changing through the use of Internet. We want to analyse how this new relationships are possible on national level. It is relevant to analyze these possible new relationships, product of social and technologic changes which allow new interactions and participation that at the same time imply changes in organization forms, web resources management and teaching and learning models.

\footnotetext{
${ }^{10}$ http://www.nhm.ac.uk/nature-online/index.html

11 http://www.24hourmuseum.org.uk/

12 http://www.show.me.uk/

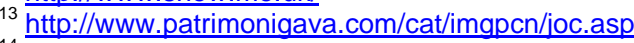

${ }^{14} \mathrm{http}: / /$ www.fabricadelesarts.cat/cat/LlistaEntrevistes. php

15 http://www.mnactec.cat/ensenyar aprendre.php?idioma $=0$

${ }_{16}$ http://www.lapedreraeducacio.org/flash.htm

17 http://www.maletapesca.org/

${ }^{18}$ www.xtec.cat

19 www.edu3.cat

20 http://clic.xtec.net/ca/index.htm

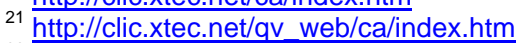

22 http://www.xtec.net/recursos/webquests/

$23 \frac{\text { http://phobos.xtec.cat/audiovisuals/radio/ }}{2}$

24 http://www.edu365.cat/eso/muds/socials/index.htm
} 
We can find virtual repositories (European Schoolnet, 2006) of online educational resources with digital cultural heritage content on webs of museums, media communication companies, like BBC ${ }^{25}$ or TV3 ${ }^{26}$; telephone companies, like Telefònica ${ }^{27}$ or Deutsche Telecom ${ }^{28}$; education departments of public administrations, like the Department of Children, Schools and Families ${ }^{29}$, Ministerio de Educación y Cultura ${ }^{30}$ or Departament d'Educació de la Generalitat de Catalunya ${ }^{31}$. Preliminary analysis of online educational resources with digital cultural heritage content from Museus de Catalunya $^{32}$, Patrimoni.gencat ${ }^{33}$ and $\mathrm{XTEC}^{34}$ indicate that these resources are created by teachers or heritage managers with of support of webmasters. They present a sectorial viewpoint which could have limited didactic applications. We will analyse educational online resources with cultural heritage content from a scientific and educational point of view which will emerge through learning networks linked to a concrete social and cultural context.

The report of Projecte d'Internet Catalunya (PIC) "L'escola a la societat xarxa: Internet a l'educació primària i secundària" ${ }^{35}$, declares that a key question for the next years is if the ICT in Catalonia will be used for strengthening the current educational status quo or they will transform the learning and the educational experiences of all the children and teenagers. At an European level, and according to Lisbon strategic objectives Program Education and Training $2010^{36}$, a transformation in the educational practices is necessary. At this point, we highlight SITES 2006 Study (Second Information Technology in Education Study $2006^{37}$ ) guided by IEA (International Association for the Evaluation of the Educational Achievement). It was an experimental project of advanced integration of ICT in learning in which Catalonia with other 20 countries participated. Specifically, students of rural schools participated in module 2 Innovative Practices SITES ${ }^{38}$ where they worked in network, with ICT and cultural heritage. We will establish an experimental project where the goal is to create and use online educational resources with cultural heritage content through learning networks shaped by heritage managers, teachers and students within our social and cultural reality. This action research has the potential to generate genuine and sustained improvement in schools and other educational settings. It could provide educators with new opportunities to reflect on and assess their work, to explore and test new ideas, methods, and materials, to assess how effective the new approaches are, to share and explore feedback with colleagues, and to make decisions about strategies for instructional changes, etc. (Ravitch and Wirth, 2007).

Nowadays, there is a request for more researches and studies results that will contribute to the educational field, which is one of the big issues of our time. I will develop an action research in education and transfer micro-experiences and public knowledge to other settings so that others can see its application to their settings (Levin, 2008).

\footnotetext{
${ }^{25} \mathrm{http}: / / \mathrm{www} \cdot \mathrm{bbc} . \mathrm{co} . u \mathrm{k} / \mathrm{schools/}$

${ }^{26}$ http://www.edu3.cat/

27 http://www.educared.net/

$28 \frac{\text { http://www.lehrer-online.de/ }}{\text { htw. }}$

29 http://www.curriculumonline.gov.uk/default.htm?cookie\%5Ftest $=1$

30 http://www.cnice.mec.es/

${ }^{31}$ www.xtec.cat

${ }_{33}$ http://cultura.gencat.net/museus/muscerca1.asp
}

http://www20.gencat.cat/portal/site/Patrimoni/menuitem.ce671935e22706ad86a64e10b0c0e1a0/?vgnextoid=153dc3fec1f71 $110 \mathrm{VgnVCM1000008d0c1e0aRCRD \& vgnextchannel=153dc3fec1f71110 \textrm {VgnVCM } 1 0 0 0 0 0 8 \mathrm { d } 0 \mathrm { c } 1 \mathrm { e } 0 \mathrm { aRCRD } \& \mathrm { vgnextfmt } = \mathrm { defau }}$ $\frac{\mathrm{tt}}{34}$

www.xtec.net

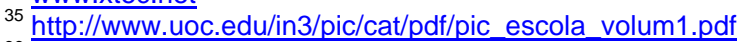

36 http://ec.europa.eu/education/policies/2010/doc/rep fut obj es.pdf

37 http://www.sites2006.net

38 http://www.sitesm2.org/mod2.html 


\section{Action Research core concepts linked to the research project}

Hilary Bradbury and Peter Reason define Action Research as:

"a participatory, democratic, process concerned with development practical knowing in the pursuit of worthwhile human purposes, grounded in a participatory worldview. It seeks to reconnect action and reflection, theory and practice, in participation with others, in the pursuit of practical solutions to issues of pressing concern to people" (Reason \& Bradbury, 2001: 1).

The core concern for action researchers is to develop practical as well as conceptual contribution by doing research with people rather than about people. Collaboratively, we seek practical solutions to issues concerning people. In Action Research, the process of generation of knowledge is understood as a research in a real holistic life situation where the knowledge is generated through an active experimentation in which participants and researchers cogenerate knowledge. Individually, I will write the Thesis and make a scientifically contribution from a local practice. Action Research provides useful results for the people and relevant knowledge in a specific discipline.

\subsection{Action Research}

Action Research is a learning process and a process where in participation with others we develop practical knowing through actions and reflections. It implies change, transformation and benefits to organizations or communities and people lives.

Like changes toward sustainability, change in education and, specifically, in heritage education or education through heritage using Internet, requires intentional micro-changes catalyzed through a logic of attraction by a compelling new vision and discourse. Action research can be of significant value in building capacity for, and in the study of, efforts in support of heritage education or education through heritage using Internet. Action researcher can be a helpful tool to foster the conversation already underway through giving a common language to many of the trans-sectoral initiatives that include people from the cultural and educational sectors, and then further telling these stories be it through publication channels or through convening forums for public conversation (Hilary Bradbury, 2001).

\subsection{Stakeholders}

Action Research is possible with, for and by people and communities, ideally involving all the participants from the Action Research project. Stakeholders give insights and help in questioning and sensemaking that informs the research. Mainly, teachers, heritage managers will work, learn and make sense together. Teachers and museum staff are also co-creating the future where they will involve the students in a future stage. They are essential for doing this empirical research and obtaining outcomes.

In fact, they will also become researchers, insider researchers. Action Research has been understood as a process in which participants can be or become researchers (Kemmis, 2008). Insider action researchers need to build on the closeness they have while they create distance from it in order to see things critically and enable change to happen (Coghlan and Shani, 2008). In addition, they will have also the responsibility to make successful the experimentation and the 
Action Research. The experimentation and insider research of each community will be a driving force for developing of new capabilities.

Outsider researchers will provide other point of view and will help to question issues that an insider researcher takes for granted or doesn't realize. They can add new dimension to the analysis and new directions to the project by researching the data posted on the virtual platform in different section and comment upon and critique the data.

The insider and outsider researchers will write a dairy (first-person inquiry), forum space or blog (second-person inquiry) and articles and papers (third-person inquiry) about experience, understanding and judgment, a praxis-reflection methodology (Coghlan and Shani, 2008).

\subsection{First/second and third Action Research}

First person reflection and inquiry is essential. It is the foundation for building $2^{\text {nd }}$ and $3^{\text {rd }}$ person Action Research. First Action Research ${ }^{39}$ is a tool that will help me systematically think about my own actions and it is a method of inquiry that will not leave things without understanding and transforming those places of unsuitable practice. First-person research suggests the impact of the research on the researcher myself (the "I"); reflection on practice as well as inner changes that occur through reflection and action (Fischer \& Phelps, 2006).

I plan to research with other people. The second Action Research builds upon the knowledge gained from first person Action Research. Second-person research is how the participants/partners in the research (the "you") are influenced and changed through the process reflection and action (Fischer \& Phelps, 2006). I will establish dialogue with the participants. I have planned a first meeting where teachers and heritage managers will come together and establish conversation. They will continue being in touch in a virtual space. During the project, teachers and heritage managers will take notes about their actions and reflections in a dairy or field note book. So, they will do a first-person inquiry and/or practice. They can reflect on themselves, on their own values and assumptions, and on how they behave. These first-person skills focus on the teachers or heritage managers themselves and require a process of self-discovery. Teachers and heritage managers will also make a collective reflection in a forum space. Through second-person inquiry and/or practice, they can engage in inquiry with each other on issues of mutual concern and can work to create a community of action and inquiry. In other words, second-person skills focus on inquiring and working with other on issues of mutual concern. Teachers and heritage managers need to turn to their colleagues for honest feedback about their personal development.

The third Person Action Research builds on first and second person Action Research and provides information intended to be useful for working with a wider group. Third-person research (the "they") encompasses the implication of the research for a broader world beyond the immediate locus of action (Fischer \& Phelps, 2006). We will provide knowledge to a wider community with particular outcomes that will make sense in education settings. Through third-person inquiry and/or practice, we can move beyond immediate first and second-person audiences to the impersonal wider community and contribute to the body of actionable knowledge. Third-person skills take the perspective of the broader picture that enables extrapolation and dissentions to an impersonal audience (Raelin and Coghlan, 2006).

\footnotetext{
${ }^{39}$ See annex an example of first person research.
} 
This research will result in relevant scientific production. On the one hand, results will be included in the thesis. On the other hand, we seek to publish articles fin journals such as "Aula de innovació educativa", "Cuadernos de Pedagogia", "Learning and Instruction" and "Action Research"; papers for Educared ${ }^{40}$, EducaThyssen ${ }^{41}$, Online Educa Berlin ${ }^{42}$, Museum and the Web from Archives and Museums Informatics ${ }^{43}$ and e-Social Science conference ${ }^{44}$; a book about these cases of learning network and online educational resources.

\subsection{Inquiry and dialogue}

Inquiry and dialogue are central to action methods in Action Research for making knowledge and learning flow. To inquire is to come across the core issues/ needs inside the system (i.e. community or organization). But, the action researcher has to inquire and nurture the inquiry and dialogue with, between and for community members. If we manage to grasp the community meaningful issues, design good meetings where productive dialogue will be occur, we can acquire useful information, understanding and deeper relationship. The issues of quality in participation and relationship can strongly impact upon the quality of useful, pragmatic outcomes. We must also extract guidelines in how we can foster a sustainable partnership based on trust and transparency. The Action Researcher must be a good observant, meet the doubts, interpret the actions and words from the members and understand the meanings. I must give adjustment answers or make appropriate actions in time and place. So, the research must be disciplinary. Disciplinary work will provide trust while transparency will be achieved by publishing documents (manuals, informs, articles, etc,) in the communities virtual spaces and providing free access of the members within each community to the mails (CMC) at the "Forum" and "Debat" area built by Drupal an open source software. The community virtual will provide a dialogue and inquiry space.

\subsection{Partnership}

Partnership is one of the four core elements that will evaluate the quality of the Action Research. In addition to nurturing a deeper relationship and participation, it is very important to establish partnership within each community because it will also imply that not only the members will look for and work together for an individual interest, but for a common interest. I have established relationships with heritage institutions and schools. But there are different kinds of action that will engage partnership. In the beginning, we have asked for an economical support "ARIE 2008" that implied a formal agreement from the different members. During the experimentation there will be other actions which will have the goal to cultivate partnership, create understanding and iengage the members in the learning experience.

Relations build structures. The action research project suggests building a network shaped by researchers, heritage managers, teachers and students. They will have tools for peer to peer knowledge development and learning. So, all practitioners will be at the same level and will take decisions together. There won't be a hierarchy and a top-down power structure. The coordination will be lead by me. I plan the project, the macro environment, different cycles, phases and initial actions. But, I will not influence at micro level. I will intervene when the situation or people required.

\footnotetext{
${ }^{40}$ http://www.educared.net/congresoiv/

41 http://www.educathyssen.org/

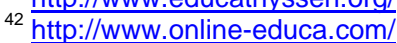

$43 \frac{\mathrm{http}: / / \text { archimuse.com/index.html }}{\mathrm{h}}$

44 http://www.ncess.ac.uk/
} 
For example, if I see that there are isolated individuals, I will take actions that will have the goal to activate members.

\subsection{Collaborative relationship}

The members will work and learn collaboratively. This practice within each community of the Action Research project will establish a community of practice where the members will generate and share experiences, stories, tools, ways of solving problems, etc. Communities of practice are groups of people who share a concern or a passion for something they do and learn how to do it better as they interact regularly (Wenger, 2001). In fact, practitioners and researchers will come together during one year to activate knowledge rested on a collaborative relationship, learning and working. They will create and use educational resources with heritage content of heritage education and education through heritage. Through social learning (Wenger, 2001), acting and thinking in a social context, we will test if this kind of learning network works or how it works in our social and cultural context. We will also see if online educational resources with digital cultural heritage content will generate a successful heritage education and/or acquisition of curriculum subjects through heritage education.

\subsection{Participatory worldview}

All the practitioners came together in the Action Research project. They believe in change or transformation. At the starting point, all the agents agree to espoused theories and lived experiences of the members. The members at the first meeting have shared their worldview. I wanted they to share their worldview by making a theatre representation about their past experiences in teaching subjects thought ICT or delivering digital heritage. From the participation in the Action Research project and, specifically, in the community of practice, will emerge a participative way of seeing or acting in the world. During the experimentation, each community can develop its own way of seeing and acting which should generate theory and practice that could be compared to the outcomes of the other communities. In other words, working with the three learning networks of the experimentation will show us three, two or one way of seeing or acting in the world.

\subsection{Reflection}

Methods, outcomes and practice in our work must be reflexive. Action Researchers must ask questions about the value of the things we are seeking to accomplish. I want that all actors involved in the project ask themselves about their own actions and experiences during and after the practice. They will get energized and empowered by being involved through which they may develop newly useful, reflexive insights as a result of a growing critical consciousness.

We propose an action research practice that is described in terms of action and reflection. We will depart from a common view point and we bring theories and real life experiences to practice. From this experiment which includes action and reflection, a new understanding will be grounded which will be compared with the outcomes from a second cycle. We will see which theories will grow or if the action will be congruent with espoused theories. We may develop grounded theory based on what people said and how they dealt with the issues that faced them. 
The insider and outsider researchers must also reflect on their identity/ies, roles and relationship, etc. I will therefore use a specific learning tool or action research method "learning history" to explore these learning experiences (Roth \& Bradbury, 2008). It won't be only a story about my own learning, but a jointly told tale of insider and outsider research. So, heritage manager, teachers and researchers will make a learning history.

\subsection{Practice Value}

Practice Value is also one of the four core elements for evaluating quality in Action Research. Action Research as a practical art charts different ways where people could work together for creating opportunities (Gergen \& Gergen, 2008: 10). The members ${ }^{45}$ of this project believe in a change or transformation through heritage education or education through heritage using Internet and they will work together to prove new learning opportunities.

They will define collaboratively their needs. Concretely, they will be empowered from moving from knowing something to being able to produce positive changes that they desire or that are possible to accomplish. We will see together if the theories will be reasonable and practical. Kurt Lewin observed that there is nothing as practical as a good theory (Brydon-Miller; Greenwood; Maguire, 2003).

Networks that arise for a particularly limited purpose are more likely to be transient. But the network shaped by researchers, heritage managers, teachers and students could establish a community of practice. Members of a community of practice are practitioners. They will develop shared resources such as: experience, stories, tools, ways for solving problems, etc. The community of practice does not have the goal to be a final product, but to be a part of a life long learning journey. In addition to producing knowledge and action useful for the people involved, it can also empower them to continue in the community of practice and use their own knowledge for new practice.

\subsection{Inclusion ways of knowing}

It is another core element for evaluating quality in Action Research. The extended epistemology is foundational to cooperative inquiry, but it can be applied to everyday knowing and all forms of action research practice. I will intentionally use different resources in order to enable the flow of knowledge. Experimental knowing could be captured through direct face-to-face encounters with specific people. Presentational knowing could be reflected through a wiki where the people tell a story about their experience or using other tools or online educational resources like videos or audios. A guide for learning networks shaped by heritage mangers, teachers and students and educational resources with digital heritage content should be produced by propositional knowing. And practical knowing will be expressed through the practice embodied in the interaction of each community. It will be rooted in the skills and abilities of individuals (Heron \& Reason, 2008). It could be reflected in my field notes from participative-observation and in the notes of the co-researchers. On the one hand, with readily available tools for participants to create image, music and videos, digital storytelling is an excellent method to mobilize the tacit, non-verbal, non-written, emotional, metaphorical, playful dimension of activity and knowledge in action research (Foth, 2006) On the other hand, the ways of knowing could become a Rosetta stone in order to develop a conceptual-

\footnotetext{
${ }^{45}$ See annex Member details.
} 
theoretical integrity (Kowalski et al, 2008). We will convert the tacit or implicit learning into explicit knowledge.

\subsection{Infrastructure}

It is the last core element for evaluating quality in Action Research. We will look for delivering working learning networks within a communication space where the different members can come together in conversation. The space is an essential tool where an organization structure could be developed. I must build and leave a strong social structure in a state of an efficient learning network where members can effectively continue creating and using online educational resources with digital cultural heritage content. Rita Kowalski also wrote that the impact of Action Research continues when we are mindful of leaving a legacy, an infrastructure behind (Reason \& Bradbury, 2008).

\section{Ongoing Action Research project}

A dissertation is an individual work while, as we have explain above, the action research project is collaborative. The project of Action Research focuses in generating knowledge which is shared with the stakeholders of a system (communities or organization) and it is useful for these participants. In contrast, an academic work of research requires that thiese practices will be transferable to other environment beyond of the environment where it has been developed.

\subsection{Designing project}

I finished the first proposal of the Action Research design after the approval of my thesis project by the Doctorate Commission of the UOC. I designed a proposal project which I presented at the Colorado Technical University (CTU) in Colorado Spring. I actually assisted at the physical meeting of the master class of Institute of Advance Studies where I participated at the Action Research Seminar which was delivered by Professor Hilary Bradbury. I have done assignments of the "Introduction to Action Research" course. She has supervised my learning process and the design of first steps of the project proposal which has developed from a researcher-centred to a more participant-centred study (Ravitch and Wirth, 2007).

This project has a double target. On the one hand, I will obtain outcomes from local knowledge which will be part of my doctor dissertation ${ }^{46}$. The PhD Thesis project is inscribed within the Information and knowledge Society doctorate program of the Universitat Oberta de Catalunya $(\mathrm{UOC})^{47}$. On the other hand, I will obtain practical solutions for learning networks shaped by heritage managers, teachers and students where the members could create and use online educational resources with heritage content for the education of cultural heritage and education through cultural heritage ${ }^{48}$ of Catalan High School students.

Action Research question: How do we create online educational resources with cultural heritage content through learning network?

\footnotetext{
${ }^{46}$ Lecture prevision: June 2010.

${ }^{47}$ http://in3.uoc.edu/index.php/in3web/doctorat 1

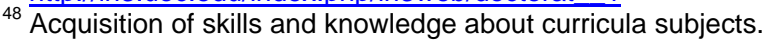




\section{Targets:}

- To establish partnership among heritage managers, teachers and students.

- To offer working and good practice of learning networks and online educational resources with cultural heritage content for the education of High school students.

- To establish a learning experience where we will understand: how the members learn to work together and handle virtual tools; how the members acquire knowledge; how they create and use quality online educational resources; how they establish teaching and learning processes.

- To analyse teaching and learning processes and resources.

\subsection{Contacting Stakeholders}

I planned that each community will have a teacher and a heritage manager member. Every Heritage institution has designated a fix person who will participate in the research. The heritage manager must have knowledge about digital heritage and ICT skills. One teacher of each school from three different high schools will also take part in the project. The teachers must have ICT skills and experience in using ICT in the classroom for teaching and learning curriculum issues.

On the one hand, I visited the Catalan leading museums and heritage institutions which are innovative in the World Wide Web. On the other hand, I contacted innovative High School teachers who were working with ICT in the classroom. I made a state-of-art about online learning network shaped by teachers and museum staff and online educational resources with cultural heritage content at an international level.

In the beginning, my advisor asked for an economical support "ARIE 2008" for the project. This implied a formal agreement from the different members. So, this decreased the risk that the members could leave the project. Teachers and museum staff were enthusiastic (Lüscher and Lewis, 2008) about the proposal to do an experiment which could imply the creation of a learning networks shaped by heritage managers, teachers and students, and creation and use of online educational resources for students. However, during the experimentation, I will have to do actions which will have the goal to cultivate partnership, create understanding and establish learning.

I had also sough outsider researchers. On the one hand, there were two external teachers interested to look on the project. They were from another high school in Catalonia. On the other hand, my advisor and two other professors wanted to take notes by doing sporadic inside observations of the communities. Finally, I contacted a webmaster. He will also become researcher.

The webmaster has created the community through the open source software Drupal ${ }^{49}$. He also established also participative tools (wiki, blog, podcast) which the members have required. He will give technical support. After the experimentation, it was planned that each heritage institution would be able to take care of the virtual platform and educational resources where the cost of hosting must be considered in the budget of 2009. These platforms will be hosted at a server at "Barakia, cultura i noves technologies" 50 .

\footnotetext{
${ }^{49} \mathrm{http}: / /$ www.barakia.com/parcarqueologicgava/

50 www.barakia.cat
} 


\subsection{Reflective work before meeting Stakeholders}

Preparing the first meeting with each stakeholder and going beyond the goals, action research questions, system map, economical, technical and academic resources, Action Research methodology etc., I start with the idea (and conceptualization dimension) that the groups and, later, each community will go through different stages of development (Mackewn, 2008). Next, I give an example of first person inquiry that firstly unconsciously and then consciously, went through my mind, while facilitating a group which is at the first or forming stage of group development. Now I am facilitating a group which is being shaped. A new group needs to be welcomed, to feel sure and valued, needs to understand the purposes (instrumental and theoretical), limits and structure of the group (Mackewn, 2008). I asked myself, what can I do so that the stakeholders and then all members of the group will feel sure, valued and welcomed? In response to my own inquiry, I can visit stakeholder individually and create connection through informal interviews.

\subsection{Meeting Stakeholders}

I made individual interviews with the stakeholders because I wanted also to know the different questions, purposes, fears or uncertainties, hopes and points of view of the agents that will participate in the experimentation. I gathered data by using an interview dairy (Taylor and Bogdan, 1987). Then I was able to design the first face-to-face meeting. The other meetings will be online. Only the last meeting will be again face-to-face and it will have the goal to validate results.

I began to thank them for the involvement in this project and I highlighted the importance of their work done up to now and the relevance of their participation. I explained the project, the purposes, human, economical, academic resources, publishing outcomes, and answered questions that worried each one of them. Teachers and museum staff could choose which cycle they would participate in. Mainly the museum staff would like to had a timing map with actions to do. So, I explained and it was necessary to draw the structure of the project and the schedule. But I noticed that it wasn't clear. Afterwards, I asked myself, how could I provide a better understanding of the structure of the project and the time planning which will also help the people to feel sure? In response to my own inquiry, at the first meeting, I can show graphics about the structure of the group and communities and a map with the tasks distributed through the year. The visualization may give clear ideas. Each action needs a reflection.

The first informal interviews had also the goal to grasp personal interests and guide the personal interests to the common interest. Individuals interest and concerns are taken seriously as meaningful and significant. The personal interests coincide and it is mainly learning and, then, obtaining working infrastructure and tools for teaching and learning. Mireia Forasté (MF) and the director of the local museum would like to know if teachers and heritage managers could work together through the Internet. They said that it is difficult job to work with teachers off line. They also seek to learn about web resources management and teaching and learning methods through the Internet. They would be able to work in the line of the proposal in the future ${ }^{51}$. On the other hand, Antoni Rius (TR) can obtain a working infrastructure and tools. Mainly, he wants educational resources with cultural heritage for schools because he will present the Virtual Museum of the Patum $^{52}$ in November 2008. So, he will show a working platform with educational resources with

\footnotetext{
${ }^{51}$ Interview 25/07/08

${ }^{52}$ UNESCO intangible heritage
} 
cultural heritage for schools which will have been evaluated ${ }^{53}$. Francesc Forn (FF) was a little bit skeptical with the purpose. He thought that they will work and I will only look for obtaining results for my thesis. I can't forget my personal interest which is also learning and obtaining results to conclude my thesis, but I explained that teachers, museum staff and students are essential for doing this empirical research, achieving the goals and obtaining relevant outcomes for each involved party. I repeated the goal of this project and the methodology. I looked for picking up FF personal interest. I think that he would like to do his dissertation. FF have created and written about a History laboratory within a classroom. Specifically, he built a History laboratory according to the learning forms that people have, VAK (visual, auditory and kinaesthetic) system. I proposed to elaborate online educational resources with cultural heritage content according to the learning forms that people have, VAK system. Another personal interest is having a purpose to have to use the computer classroom of the school ${ }^{54}$. Finally, Guillem Vallejo (GV likes innovative projects and he is a go-ahead in his classes. He will also be cathedratic. So, he has to do courses, collaborate in projects, etc. for obtaining a higher punctuation ${ }^{55}$.

Action Researchers seek and change together with subjects of the reality according to their (Actions Researcher and subjects) real needs (Gayá; Reson and Bradbury, 2008). The stakeholders like the idea to do an Action Research. In fact, José Manuel Rodriguez (JR) affirmed that it was one of the reasons why he chose to participate ${ }^{56}$. Like Robin McTaggart, he is dissatisfied with the educational research tradition in which he was introduced (Gayá; Reason and Bradbury, 2008). He also explained that it is time that the theorists do not impose education practices that do not answer the real educational needs ${ }^{57}$. Action Research promotes critical reflection; they need not be reliant on theorists external to their environment to guide their knowledge (Raelin and Coghlan, 2006). Cohran-Smith and Lytle (1993) assert that teachers have not an active voice in educational theory and research. Action Research provides a collaborative framework for working with teachers to strengthen their voices (Ravitch and Wirth, 2007).

The first individual interviews with each stakeholder also helped me to go on with the Action Research design and to shape the communities. I think that it is relevant that the stakeholders of each community have a common interest which is linked to the cultural heritage item or its location. FF studied archaeology and the Museum of Gavà is a deposit, an archaeological park. This year, he will teach prehistory in the school. JR have worked with memory in Palafurgell while currently in Fàbrica de les Arts (Fàbrica Roca Umbert) he has done a big work of gathering oral histories of the people linked to this factory and it is beginning to teach contemporary art. Ester Prats (EP) explained that they will inaugurate an audiovisual exhibition in November. She finds JR profile very interesting because JR had done a lot of work i.e. he worked with children in risk of exclusion using art education. His school has a production company ${ }^{58}$. Fàbrica de les Arts is in Granollers where JR has familiar members living. He is often in Granollers. In other words, he has a personal link to this city. GV is a poet. The poesy, the theatre, the tradition are intangible heritage. He would like to see how we will show the Patum (intangible heritage) through online educational resources which at the same time will be linked to the curricula subject "Spanish language and literature".

\footnotetext{
${ }^{53}$ Interview $1 / 08 / 08$

${ }^{54}$ Interview 6/08/08

${ }^{55}$ Interview 24/08/08

${ }^{56}$ The other one reason is that the school needs a project which considers the audiovisual education. They achieved all goals in the first years of the three year of economical support which is for being an innovative education center in audiovisual education.

${ }^{57}$ Interview 18/08/08

${ }^{58}$ http://www.b7films.org/
} 
On the one hand, the heritage managers are relieved because the teachers have ICT skills and experiences in teaching and learning with ICT. JR is also looking for software (for example, Ardora ${ }^{59}$ ) which will be easy to use for all kinds of students. He has a diversity of students in the classroom. Heritage managers also appreciate that the teachers know about the heritage that their Institution represents and that they recognize its value. This fact has stretched an emotional link between teachers, museum staff and heritage. It would seem timely to help bring more focus to the positive emotional elements in people's engagement and build on people's desire to be a partner in something that has meaning (Hilary Bradbury; Phil Mirvis, Eric Neilson \& William Pasmore, 2008).

\subsection{Planning first meeting}

On the one hand, I knew and I respected the skills and perspectives the teachers and heritage managers would bring to the learning environment and could therefore understand and use many of their suggestion as part of the design and implementation of the initiatives. On the other hand, I knew that mainly the instrumental purpose motivated people. So, it can catalyse the group's energy to achieve breakthrough into transformative action. As a facilitator, I intervene in supporting these purposes and suggestions and I will plan the actions, design and replan the ongoing action research (Mackewn, 2008).

At the first meeting, I planned to invite three heritage managers, three teachers, five researchers. I planned the starting structure ${ }^{60}$. Action Researcher would invite every one to introduce themselves and to say a few words about their background and institution. I wanted that each person spoke about their experiences, for example in designing resources like audios, using participative tools or the VAK system.

I planned to explain Action Research and how I linked the project to the dissertation ${ }^{61}$. Then, I planned to show cases of online educational resources. The webmaster would be able to show the virtual platform and he could give a feedback about questions. On the one hand, we would be able to cultivate specially partnership between the members of each community and teach reflexive practitioners work. I also planned for the first meeting group dynamic activities which had the goal to make practitioners begin to work with each other, which implied meeting people and creating a trust feeling between members and their actions. On the one hand, it provided a preunderstanding of people knowledge and experience which was relevant before they engaged in a research program (Coghlan and Shani, 2008). On the other hand, it would allow to show concerns and conflicts which I must envision in a future stage. Integration and creative approaches and presentational knowing are ways of working with own and with the group's energy (Mackewn, 2008). The demand for practical tools and methods to elicit, document and interpret expressions of tacit knowledge may be met through acts of sociocultural animations that provide community members with opportunities for creative expressions (Foth, 2006).

The activities sought to introduce creativity which is required in this kind of work. The art of facilitation is to introduce creative experiences, but it takes people outside their comfort zone. I planned to give relevant and rational reason for introducing these activities. The group would be energized by the novel approach, the individuals would be inspired because their rational and intuitive minds were working together, both individual and group had access to intuitive hunches

\footnotetext{
${ }^{59}$ http://www.aspepc.es/displayarticle404.html

60 See annex Agenda first meeting.

${ }^{61}$ See annex Core AR and thesis in ZUBER-SKERRITT and FLETCHER's schema $(2007$, p.421)
} 
and personal and collective wisdom which were previously missing or unvoiced (Mackewn, 2008). Action researchers have to build relationships and trust between people (stakeholders, researchers) who operate from different mental models and at different levels (Coghlan and Shani, 2008). I had to plan different kind of activities according to different kinds of knowing (Heron and Reason, 2008).

\subsection{Observations}

After, member's introduction, I went on about Action Research concepts because I sough to introduce the members in the methodology and their dual role as teacher or heritage manager and researcher. I showed examples of educational online resources with cultural heritage and tutorials of software for developing these kinds of resources. I followed the agenda. They listened and made more comments than questions.

I used a system tool in Action Research. I have showed system maps ${ }^{62}$ because a visual map could provide a better understanding and support thinking about the organization structure, space and time.

Figure 1. Interaction first cycle. Two communities will interact independently from September to December 2008

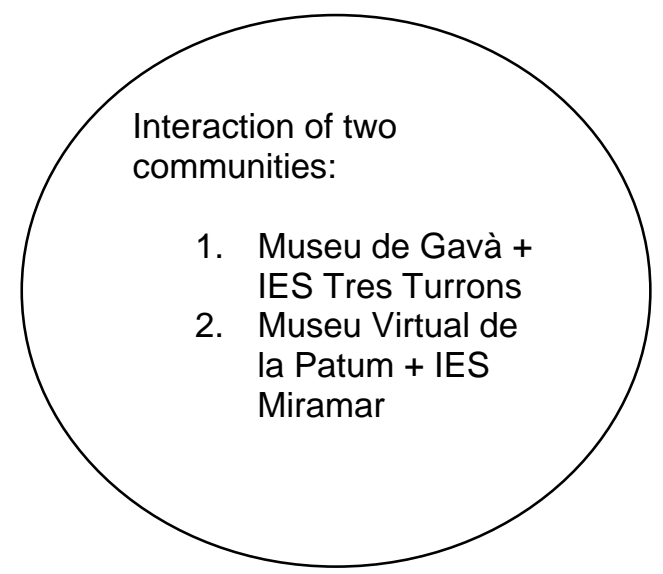

Figure 2. Interaction second cycle. One community will interact from February to May 2009

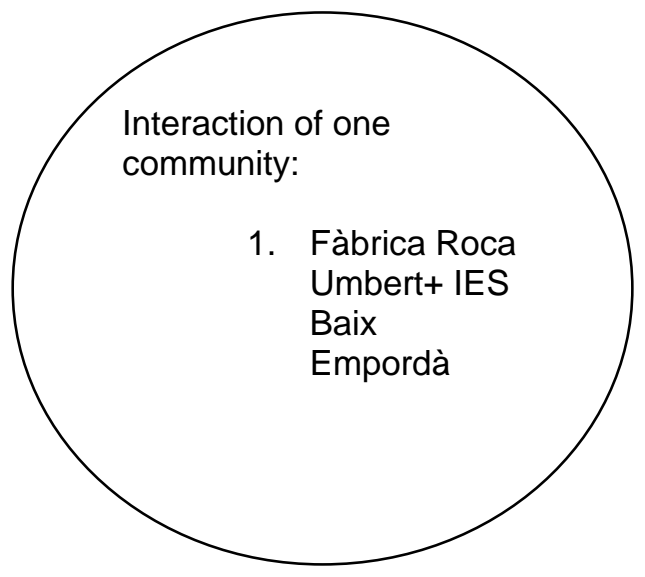

${ }^{62}$ See annex where is another system map. 
Fig. 3. Teachers and heritage managers intervention. Members interaction within 1st phase of the 1st cycle
Fig. 4. Teachers, heritage managers \& students intervention Members interaction within $2^{\text {nd }}$ phase of the 1 st cycle

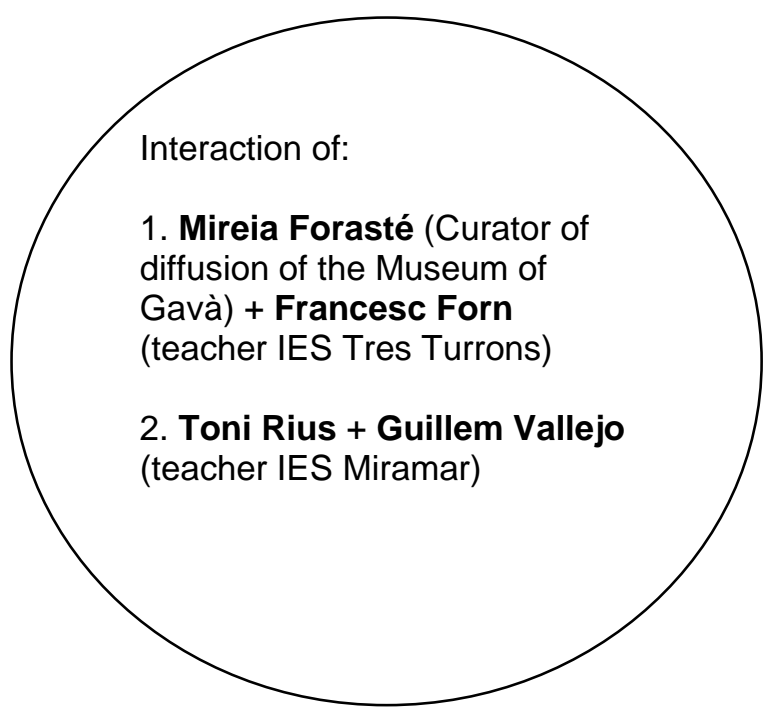

Fig. 5. Teachers and heritage managers intervention Members interaction within 1st phase of the 2 nd cycle

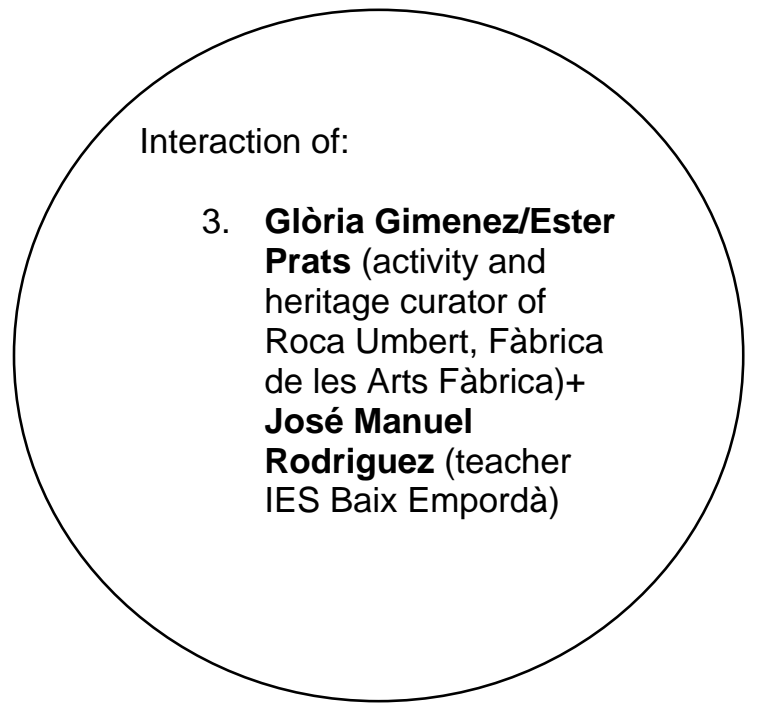

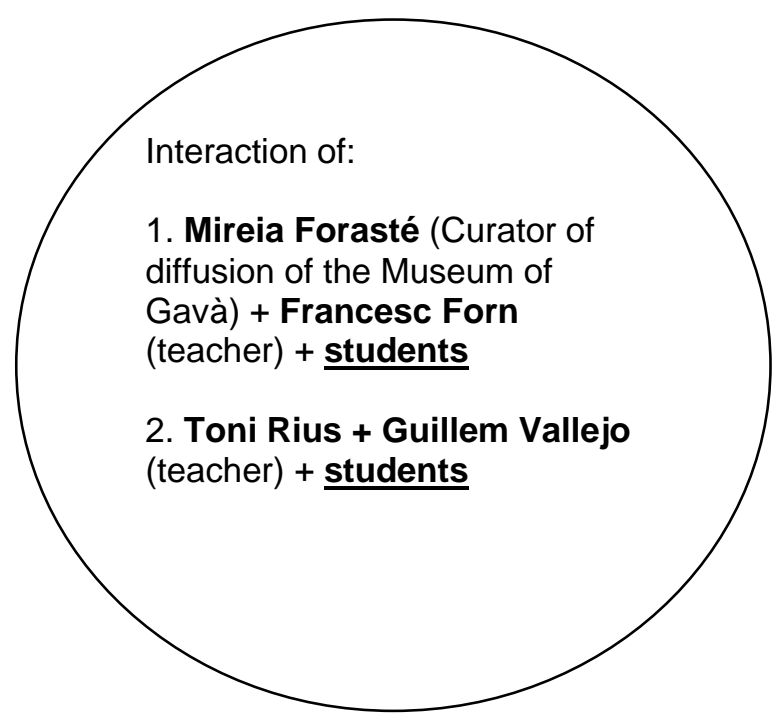

Fig. 6. Teachers, heritage managers \& students intervention Members interaction within 2nd phase of the 2nd cycle

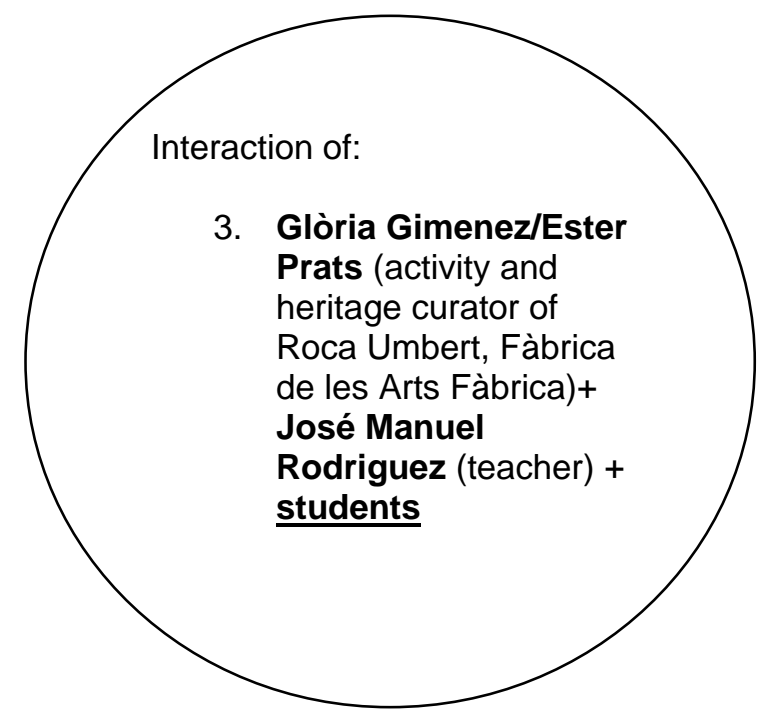

Outsider researchers will be present in each community. In the end, there will be only the PhD Professors while the two other teachers didn't give an answer about the announcement to the meeting. 
Fig. 7. Actions $1^{\text {st }}$ cycle and $1^{\text {st }}$ phase. Planned actions from 15 th September to 26 th October

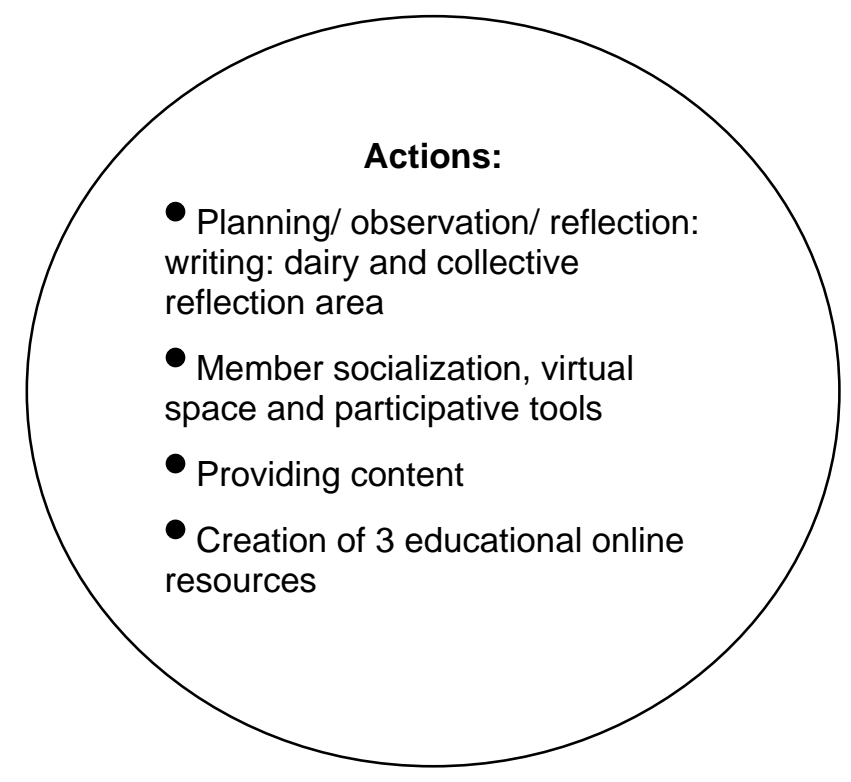

Fig. 8. Actions $1^{\text {st }}$ cycle and $2^{\text {nd }}$ phase. Planned actions from 27 th October to 21 st December

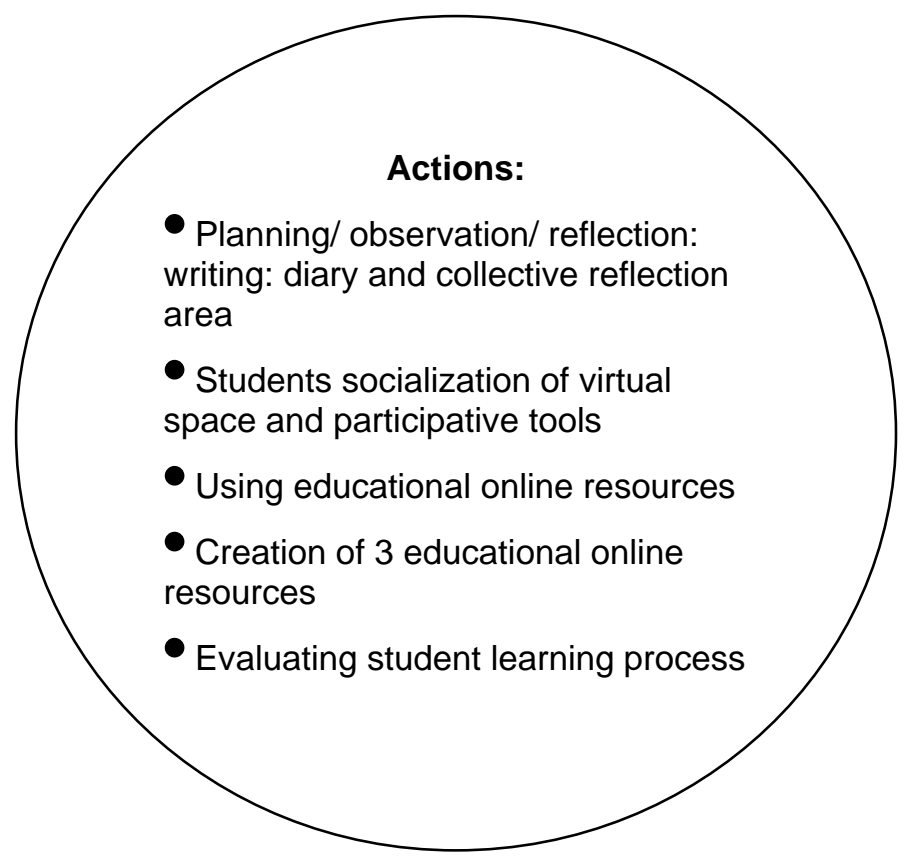


Fig. 9. Actions $2^{\text {nd }}$ cycle and $1^{\text {st }}$ phase. Planned actions from 2 nd February to 16 th March

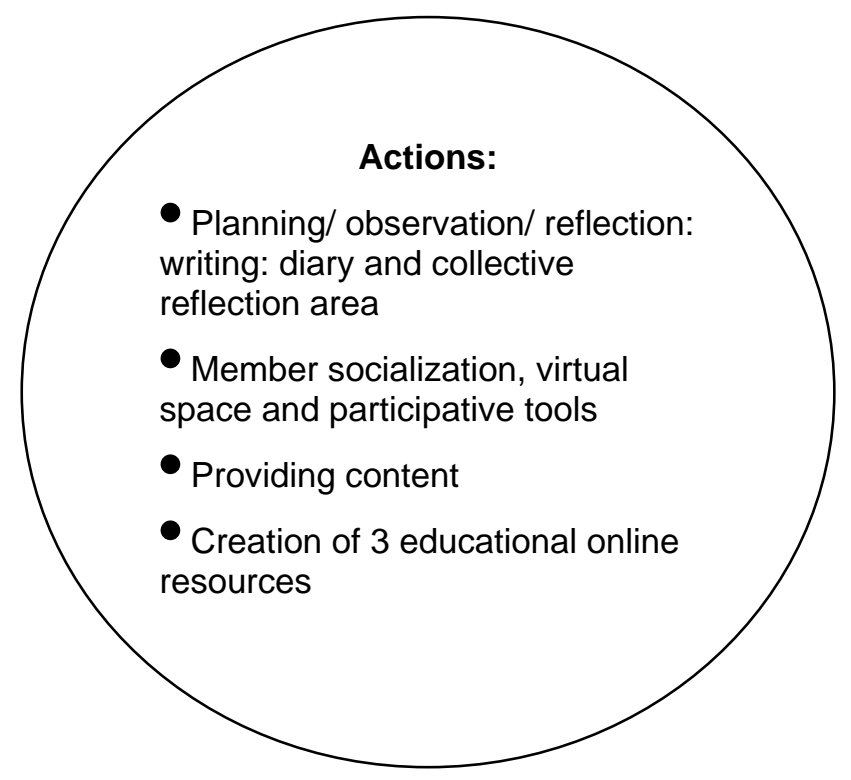

Fig. 10. Actions $2^{\text {nd }}$ cycle and $2^{\text {nd }}$ phase. Planned actions from 16th March to 17 th May

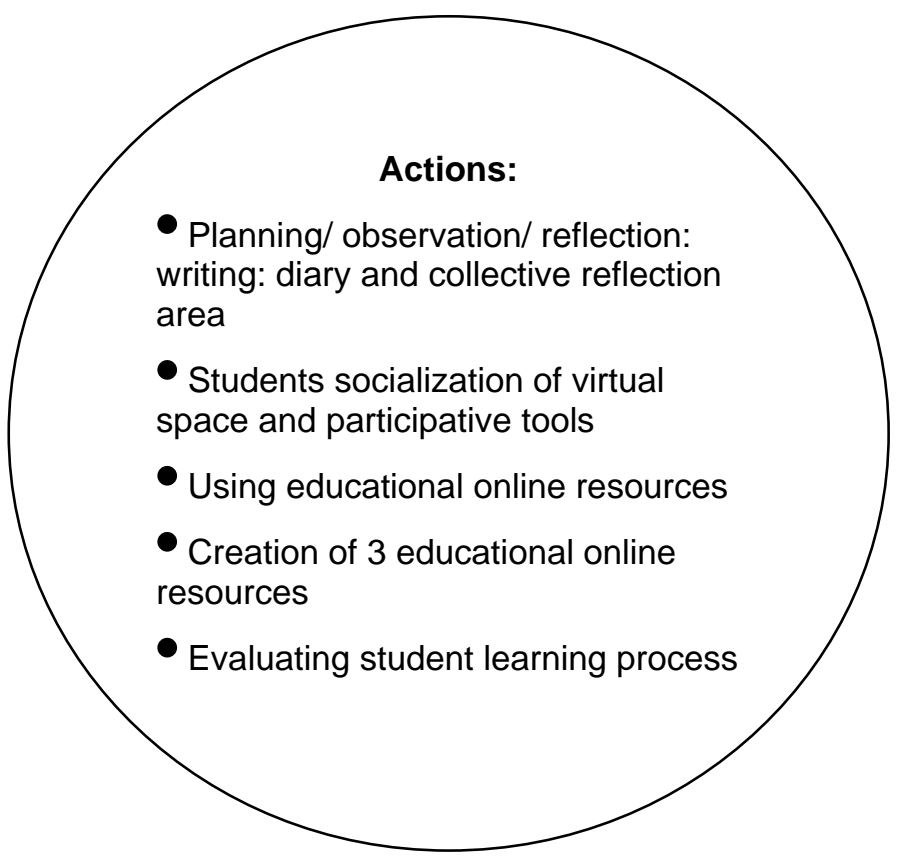

During webmaster's presentation, I introduced them to second-person research. Through secondperson voice/ practice we engage in inquiry with other and work to create a community of inquiry which was shaped at the meeting, but, it will meet at virtual space. Each community will co-inquiry about the specific tasks, they will co-design and execute the process within the inquiry virtual community. The full members must also understand that they will inquire into the working of the system. It can be understood as undertaking insider action research (Coghlan and Shani, 2008). The experimentation of new organizational structures and insider research within each community will be a driving force for developing new capabilities. The insider action research is a role as a learning mechanism, and the outcome should be effective for developing new and applicable organizational capabilities. 
After the presentation of the virtual platform, I had planned activities where the outsider researchers would be able to observe and take notes about the observations. But from three planned activities about practitioner's reflexive work, we have done only two. It was a very long and intensive meeting. Torbert proposes reflexive practitioners work (Taylor; Rudolph and Foldy, 2008). At the first meeting, I wanted to teach it and I planned activities in "Key concepts and practices" which was inspired the practices samples of Taylor, Rudolph and Foldy chapter at the "Handbook of Action Research. Participative inquiry and practice". The first key concept was "Social construction of reality". We must understand that we construct socially the reality. The goal was understood that we socially build the reality. It sought to show the internal organization of the communities and how emotional reaction and action influenced and co-create the organizational structure and practice. The second key concept of practitioners reflexive work was "Self contribution to the social construction of reality" while the third was "Taking action to reshape our reality" which we did. I also wanted to give teachers and heritage managers homeworks. But, they seemed tired and they wanted to finish the meeting.

\subsection{Results}

At the beginning, I suggested three independent virtual communities because usually, teachers don't like that other teachers observe their work. In fact, there are teachers which are used to teach in the seclusion of their individual classroom and there is little collective sharing of ideas (Ravitch \& Wirth, 2007). But they agreed that they wanted to work together in one virtual platform ${ }^{63}$. There will be three leaning networks in one virtual community. There will be communication structures in each learning network that I will monitor while I will also monitor the information flow between the metanetwork and sub-network.

\footnotetext{
${ }^{63}$ http://barakia.com/3c4learning/
} 
Figure 11. Meta-network and sub-networks structure and communication flows. Adaptation of Figure 2 "Rich picture of social networks and action research meta-network" (Foth, 2006)

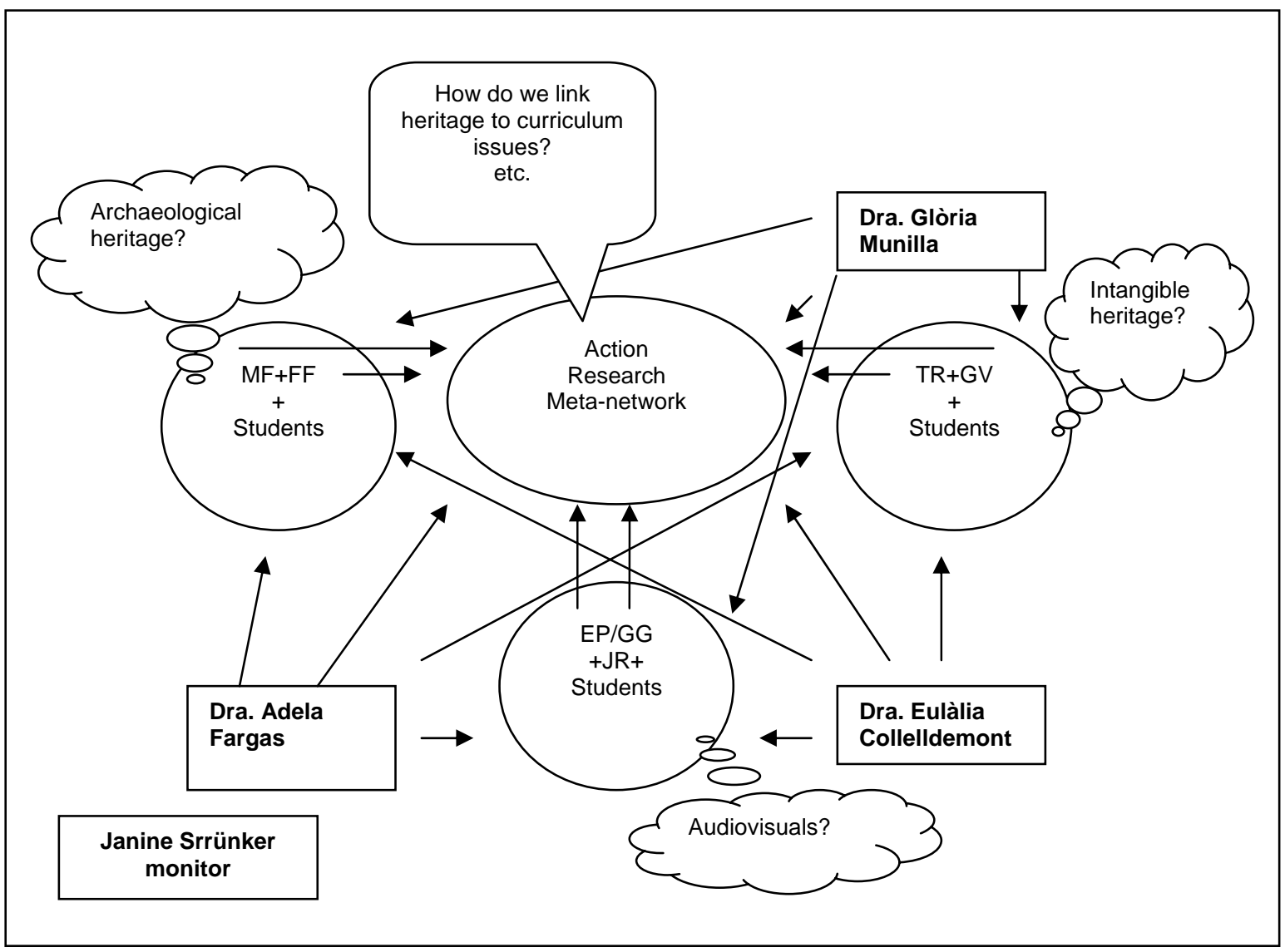

I pointed out that this will imply the participation of the members in all cycles (and project process) and that students of different level will come together in one space. On the one hand, teachers and heritage managers have make explicit that they will work collaboratively. It can be an educational way of working together (Peidong \& Ladlaw, 2006). On the other hand, this activity must be taken in account because students like this kind of interschool connection.

Heritage managers and teachers don't have a lot of time. We have only a year for developing this experimentation. I showed the schedule and we agreed about the action timetables ${ }^{64}$. More or less we established a desirable environment and desirable action. I suggested that they had to reflect about actions which will take to a desirable future. So we should avoid undesirable results. Firstly, each member (teachers and heritage managers) made its own list. After, they shared their desirable results. One of their desirable results is learning. On the one hand, the participants advised through the activity that taken actions reshape the reality. On the other hand, they noticed the expectations of every member and the different points of view.

It is a learning process. We have agreed that we will learn from this experience. So, the dairy or private blog is a relevant tool for reflecting the learning process. The common communication space, forum, will be another fundamental tool where the members will establish dialogue. It is a space of collective reflection and a critical space. The creation of critical space involves not just

\footnotetext{
${ }^{64}$ See annex schedule.
} 
questions from building a relationship with people inside of the virtual platform, but also a conversation of practice. An emerging hypothesis is that the forum or meta-network space (Foth, 2006) will become a discussion area according to research themes or community issues and documents network as well as collective action and progress.

Action Researcher has to be aware of the preferred communication channels that are used by members of the community to exchange information and to network (Foth, 2006). They decide to eliminate wiki because there were too many participative tools. A part, the wiki caused disconcert of few people who don't know how to use this tool. The participative tools chosen are easier to use. It is impossible for an action researcher to ignore what people think and want (Brydon-Miller, Greenwood and Maguire, 2003). So, we established a desirable environment where the members can feel more familiar and comfortable. I made the reflection about the fact of the social construction of the reality. I had facilitated a dialogue space where a multiplicity of perspectives come together. For example, heritage managers have interpretative keys while teachers have the pedagogical keys. Heritage managers will provide digital heritage and the teachers will give form the materials and activities according to the learning objectives. Heritage managers will learn pedagogical techniques and teachers will acquire knowledge from heritage. I made the reflection about the fact of the self-construction of the reality. I wanted they to feel implicated within the system by recognizing their contribution in this construction.

The participants noticed that Action Research is learning. We agreed that our learning could provide an exportable model. The goal is to capture what our innovative group learned and can transfer from their new knowledge to other groups and organizations. A few members have taken into account that we will learn to develop new capabilities. Capabilities are the know-how that enables an organization to achieve its intended outcomes (Coghlan and Shani, 2008). In an ever changing world, developing new capabilities is widely viewed as a necessary strategic for organization across all sectors (Coghlan and Shani, 2008).

\subsection{Reflection and action}

I think that I want to clarify too many things, I must try to not explain everything and let them discover some of it by themselves (Peidong \& Ladlaw, 2006). Actually, it was a long meeting. A researcher expressed this observation which I also had advised. On the other hand, few members expressed their amaze about the power of convening that I have managed. This observable fact reasserts that people believe in this project. In fact, the participants believe in a change or transformation in the education sector. We have opted for this education proposal project which implies to shape learning network where the members will create and use online educational resources with cultural heritage content. We will test it in the practice within a concrete social and cultural context because we believe that from the practice will flourish the theory.

After the meeting, I sent a mail where I attached the Power Point presentation and the email list of the participants. A part, I had given thanks for their participation and trust. Then I followed exposing the fact that it was a long meeting and that I dared (little joke) to give them homeworks. I explained the purpose of the dairy which I have described previously in this document. I also indicated that if they could take notes more honestly and descriptively, we chould extract and, afterwards, we could communicate more knowledge.

On the one hand, I remembered the relevance about the reflexive practitioners work and the collective reflection which I think that weren't $100 \%$ noticed by the participants. I also explained that 
I will seek inclusion ways of knowing and make actions to make knowledge flow where tacit knowledge should be reflected. As I have aid above, inclusion way of knowing is one element that will measure the quality of the Action Research which I must take into account.

At the email, I explained that we will integrate three manifestations of work, first/second and third person Action Research. It will be a work for me (PhD), work for my partners (gaining experience, knowledge and working model) and work for people from a wider context (i.e. comparable model for other institutions or organizations). The data and information will be of all members. So, I advised that we will publish together when we will have validated the results. We must agree not to use any Confidential Information as a basis upon which to develop or have a third party develop competing or similar products.

In the end, I indicated that if they will exchange mails or they establish meetings, I would like to know it because they will produce data for analyzing. I also wrote that I will support them if they need help, for example with a software of participative tool of the platform. It was the major technical fear expressed in the meeting. In fact, teachers and heritage managers communicated a fear of change, sharing insecurities about their ICT skills. I hope that the elimination of the wiki will give new power to the participants with less ICT skills.

I remembered the instrumental changes and I pointed out that there will be only one platform. I am expecting that the heritage institution do not complain. Even it was also their decision to make one platform that worried me, because they won't have their own virtual infrastructure. I (we) must seek which infrastructure I will leave behind (Reason \& Bradbury, 2008:49).

The webmaster is designing the top of the webpage where we will identify the three heritage institutions. He is also creating the user names and passwords. Currently, the members have provisional user names and passwords. I invited them to navigate through the virtual platform and make a contribution at the forum or blog. But, they did not still make a contribution. That make me very nervous (Heen, 2006), but I must take it patiently and think about it and what can I do.

It was a long mail. I am also waiting that the members answer. EP has sent me a mail with the mail and last name of Glòria Gimenez (GG) while GV said me that he will receive a mail from TR because they will establish a physical meeting. They think that it will accelerate the work. The classes have started. Heritage managers also have finished vacations. I must wait and be patient. Sending everyone with the same message through the same channel is a form of introducing a more democratic process that supports reflection and action outside the traditional knowledgegenerating institutions, entities and individuals (Foth, 2006), but it is possible that they should like more personal/individual messages.

I spoke with the Education Department of Generalitat de Catalunya asking for the Pinnicle software. A first answer was that they do not work with heritage institutions. But they suggested that I should speak with another person. I asked him by mail if it is possible that they could install this software at the heritage institutions or if they can suggest other software e.g. open software which could be accessible for these two kinds of institutions. At the first meeting, we noticed that the High Schools work with Pinnicle software. So, the heritage institutions will need the same software, if they will work together. I have found Pinnicle software, which it is free. But, I must ask about the version which is accessible at the high schools. At this point, I must reflect on the way in which I establish a social network of informants and participants in the study and examine how they serve as resources for generating particular data. The participants will also network in an effort to develop the infrastructure for sustainability and ongoing learning networks and educational online 
resources with cultural heritage content. Gustavsen said that to learn from practice, research needs to develop social relationships; internally within the research community as well as in relation to other actors. And research cannot stay outside this process and remain as isolated individuals looking at the world from up above (Foth, 2006).

\section{Data collection, analysis and validation}

Most doctoral Students are trained in quantitative and qualitative research methods, but not in Action Research. However, presently, Action Research courses are appearing in graduate programs. Unsatisfied with quantitative and qualitative researches for reaching my research objectives, I had luck to be introduced in Action Research, a pertinently way of knowledge generation and different from other social sciences researches.

I will use learning history which is an action research method and quantitative and qualitative methods and techniques for gathering data. In developing conceptual-theoretical integrity, I will use quantitative and qualitative data. I will triangulate data and I will validate the outcomes together with the members.

\subsection{Quantitative data}

The quantitative data will come from the database of Drupal. This kind of data will show us the organizational structure through the communication flows. A network could be a social structure. In a network, first of all, there is communication (with intrinsic items, i.e. power and identity) which involves the transfer of information between individuals. People group relations serve as both limitations and opportunities for their action as a group. Moreno ${ }^{65}$ argued that the construction of sociograms ${ }^{66}$ allowed researchers to identify leaders and isolated individuals. The analysis of communications flow could show us the network structure and the group cohesion. The cohesion group analysis should bring us to study the network through the network social analysis. I will show the relationships between the actors. So, I will also establish the organizational structure of the network. The quantitative data should be collected by questionnaires. Specifically, I will gather the communication degrees that each actor establishes to other members within the same network. The degree of communication frequency gives us two kinds of information. On the one hand, an actor will show us if it has connection to other actors. On the other hand, it will inform us if it establishes more or less communication to particular actors. In order words, the interactions could vary in their frequency and directions. Through the degree of communication frequency, I will know the group cohesion. The sociometry measures the degree of election and reproach of an actor and focuses their position inside of the group. However, this technical mechanism does not show the cause of the preference or rebuffs of the subjects. We will not only have a study that will describe the organizational structures of each network without a qualitative analysis of the communication flows. The use of methods and techniques of network analysis offer useful mechanisms applicable to different fields. Sociogram is a technique that will help the practitioners to think about the system in a future stage.

\footnotetext{
${ }^{65} \mathrm{http}: / /$ www.institutojlmoreno.com/

${ }^{66}$ The sociometry measures the degree of election and reproach of an actor and focuses their position inside of the group. However, this technical mechanism doesn't show the cause of the preference or rebuffs of the subjects.
} 
The emphasis on this kind of data is the fact that we can map the social participation and think about it in an open space for being critical (Howes, 2001). Mapping sociograms is another method and technique that will help the practitioners to think about the system in the future.

We could also know which, when and with which frequency the actors use the participative tools. But, the qualitative data will provide us knowledge about how, why or which effects have the participative tools for supplying a satisfactory co-learning during the creation and use of educational resources.

\subsection{Qualitative data}

Mainly, I will have qualitative data which will be gathered from documents and other kinds of resources, observation, participative-observations and interviews. This kind of data will come from information collected by teachers, heritage managers, students and researchers. We will use the follow techniques:

- Field notes from teachers, heritage managers, students and researchers

- Recording of electronic texts, audios, videos

- Essays: wikis, interactive games, etc.

- Inform writings

The files stored in different areas of the virtual community platform play a crucial role in this project. Blogs and forum will be areas of file-sharing, collecting, storing and archiving all sorts of digital artefacts including written documents such as reports, agendas of meetings, invitations, news and audiovisual files such as images, maps, photos, diagrams, recording, songs and videos. The filesharing area should become a gallery to showcase the wealth of knowledge, skills and experiences and the progress made by the community. They function as a central online repository that reflects the virtual composition of the projects community memory (Foth, 2006). The open access of all members to the forums and blogs (not personal Blogs) will bring more transparency.

These resources reflect tacit knowledge. One purpose is converting the tacit or implicit learning into explicit knowledge (Raelin and Coghlan, 2006). In fact, the debate about recognizing the importance of tacit knowledge is an ongoing theme in action research, design and community literature (Foth, 2006). It is also relevant to note that literature encountered throughout the research will either support the researcher's current action or challenge her perspective, assumptions or approaches. Literature is more important in shaping the ongoing development of action research than informing its initial foundation or relating its findings to other research. Like I have been doing, I will take notes of up-to-date literature review because literature cannot be predetermined and of the quality action research will show how the writer has engaged with the literature and how this has challenged views. The literature that has influenced the research process or its interpretation might be also triangulated.

During the experimentation, I will do a learning history and a dairy where I will take notes about participative-observation. I will gather facts and information. I will describe observations, experiences and feelings (Heen, 2006) and I will take notes about questions and hypothesis that will arise from the writing and reflection of action. This will take time, but it is an essential tool for learning and it is a method of inquiry that will not leave things without understanding. The field book will reflect data from a reflective method about the situations, interactions of the members and about my own intervention. This exercise must be disciplinary, if I want to obtain rigorous scientific qualitative data. The qualitative researches imply successive and continuous deep reflection where 
I must also evaluate methods and techniques for gathering data and information which will be analyzed and interpreted.

Action research is not about testing preconceived hypotheses, but it is about depicting the context, change processes, learning results and theorizing of individual or group in a process of mutual change and inquiry. I will experiment with inductive approach, in other words, I will not start from explanations a priori within a context. It implies more of less an ingenuous observation and participation. This point of view is difficult to achieve because I have pre-established ideas and referent theories. If the point of view is enough ingenuous, the theory will evolve at the same times as actions and reflection go on.

In Argyris and Schön (1974) terms, researchers and facilitators (Mackewn, 2008) working in the practice field are more able to uncover participants and their own "theories in use", rather than just their "espoused theories". This experiment includes action and reflection where a new understanding can be grounded which will be tested in the second cycle. All the data will be triangulated. The results will be shared and discussed by stakeholders and researchers. After the analysis, we will meet and validate results together. Action research emphasizes the evaluation/validation outcomes and achievements as measure of quality and rigour (Brydon-Miller, Greenwood and Maguire, 2003).

Figure 12. Adaptation of Lewin's loop definition

First cycle:

Second cycle:

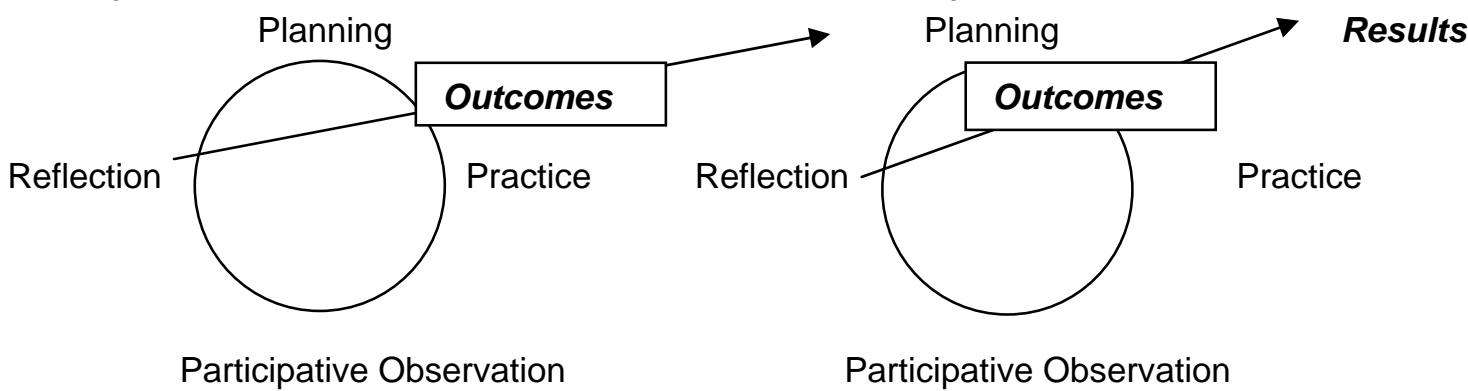

Conventional researchers worry about objectivity, distance, and controls. Action Researchers worry about relevance, social change, and validity tested in action by the most at-risk stakeholders (Brydon-Miller; Greenwood; Maguire, 2003).

\subsection{Learning history}

I wonder about the fact that Action Research establishes action and reflection in a continuously and successively way. I do not see an end. Every choice that I will make or each action that I will take after a reflection will have consequences. At the same time, it will imply another reflection and a successive action. Working on the principal of systematic conscious, there are cycle, intuitive effects and not intuitive consequence (Ison, 2008: 9). I will be immersed in a spiral cycle. I think that it is a big challenge, which implies a big responsibility. Rita Kowalski also wrote that Action Research is challenging not simply because it involves choice points, but because as you do action research, the reflection needed to complete a cycle reminds you about choices (Reason \& Bradbury, 2008: 49). 
I did not recognize that through every reflection, the action research project was/is redesigned or designed. Firstly, I was not aware that I planned actions after making a reflection. I noticed it consciously about it during the first face-to-face meeting planning. This perception challenged me to think that a deeper reflection could help me to do a better planning or establish more effective actions. I revewed again the data gathered through the informal interviews. I collected data by using an interview dairy (Taylor and Bogdan, 1987). Concretely, mainly the qualitative data analysis was essential to plan new actions practicable at the meeting. But qualitative data analysis could also support actions.

I noticed that at the future I must be stricter and more disciplined. In my opinion, I have learned reflection on action, but not in action. I have learned that it is fundamental a dairy where I will gather data from the observation and participation, but I will also need another tool where I can visualize my learning process. It will be a learning history. I will use a specific learning tool or action research method called "learning history" to explore these learning experiences (Roth \& Bradbury, 2008: 23).

At the first meeting, I was $100 \%$ conscious that each action that occurred was decision of all practitioners. I also noticed that I was redesigning the project according to the action of the participants of the project. We are co-designing. The Action Research is a mutual responsibility. The project will show how people can work and learn together. It will establish an intersubjective knowledge (Kemmis, 2008). So, and according to Kemmis, the first and central step in Action Research is shaping a communication space (Reason \& Bradbury, 2008: 49) which we have established and shaped at the first meeting. We will converse about practices and we will reflect collectively in this space. I must open more my mind and reflect about how things would have been different; how we might have acted and interpreted things differently, etc.

During the project, teachers and heritage managers will also take notes about their actions and reflections on a personal blog. It will also reflect their learning process. A collective reflection is the essence of the learning history process. So, through a planned activity, we established a common forum space where they will share information, exchange knowledge, make collective reflection, work and learn together. I had also planned other activities at the first meeting that had the goal to teach practitioners reflexive work (Taylor, Rudolph \& Foldy 2008: 46). But, I had not enough time to do it. I must take into account that the activities will be supported by me, but not determined by me (Ison, 2008:9). I have learned that everything needs its time. I must also facilitate activities that have the goal to notice and express knowledge of all participants. I must seek to find inclusion ways of knowing.

The thesis has two methodological parts. I have finished this first part, but I still have a huge work to do in the second part where this empirical research takes place. I have learned that an Action Research implies a lot of time or right planning (Bradbury \& Reason, 2003). I will deliver my thesis in June $\mathbf{2 0 1 0}$ where I must show my competence in investigation. I have noticed that I am in the fast lane in order to both handle action elements as well as the critical reflection that are engraved in the research practice (Levin, 2008). I will have to integrate a deep immersion and distant reflection in the academic memory (Levin, 2008).

The essence of the learning process is conversation between mentor and apprentice through concrete problem-solving and common reflection about action taken (Levin, 2008: 47). Now I must go on with the Action Research project and learning process. I have noticed that Action Research is very much a craft that is learned by doing, and often without any organized supervision (Heen, 2005), but I think that I will need to talk with experimented actors or/and an adviser. 


\section{Conclusion}

This working paper shows the first step in developing the second methodological part of the PhD Thesis project. We cannot yet pronounce definitive findings because our collaboration continues. However, we can explain the construction of the conceptual-theoretical framework of Action Research, linking it to the project in such a way that we have established a methodological framework where the results, practices and theories of this action research will be framed. Like indicated above, the emphasis come back to the learning experience and mainly we showed the action researcher own learning process. The learning process of collaborators and the development of the action research will depend on this learning process. So, the majority part of this document is written in first person (the"l"). The following conclusions are learning issues which highlight interventional and positional researcher implications that must be taken into account in the future action and reflection spiral cycles.

I think that doing this working paper helped me to manage my messy mind and induced me to be more reflexive about actions, concepts and myself. During the writing of this document, my "messy mind" has developed a framework which I will continue to work with. Russell Ackoff's term "messes" sum up one of the ways a great amount of action researchers differ from theirs conventional social science colleagues. Yet most action researchers have disciplined themselves to believe that messes can be attractive and even exciting (Brydon-Miller, Greenwood and Maguire, 2003). I must take into account that we are engaged in ongoing cycles of reflection and action in which our bodies and ourselves and those of our collaborators are not only presenteed to us but essential to the very process of understanding messes (Brydon-Miller, Greenwood and Maguire, 2003).

Devolving an atmosphere of collaboration is essential if the research is to be effective (Ravitch and Wirth, 2007). I need to build relationship and collaboration forms which will also include myself. Collaborating must not be as a top-down process, everyone must be involved, including me. I have learned that collaboration is a much more give-and-take situation than I previously thought. Prior to the research I felt that I provided the teachers and heritage managers with insight, but thought of it more as consultation rather than collaboration. I noticed that this approach is asymmetrical in terms of power and authority also that it worked directly against my values and goals. I must seek to become more collaborative and democratic in my leadership role.

It is important that they do not see me as an evaluator. In fact, I never have sough to be an evaluator and they never have attributed me that role before, because I have been direct in presenting the expectations of the research initiative where we participate in study both as subjects and objects with the explicit intention in the setting under study (Raelin and Coghlan, 2006). I think that the leadership role helped me to shape the group while the facilitator (Mackewn, 2008) role supports the establishment of the virtual platform and participative tools. But now I must find the path from the consultant to collaborator. I know that the rich ethnographic repository available in a near future which will be generated through the process and by community participants will set me clearly apart from mere consulting (Foth, 2006).

It is a great challenge as it is difficult to establish a balance between being researcher, leader, facilitator, consultant, collaborator, colleague and friend. Enacting participatory approaches requires me to take quite different stances; I will be a changing person. Every position that I will adopt will have consequences in the research and carrying out of the dissertation. The positioning 
of the action researcher implies methodological, ethical and epistemological implications. I have noticed that implications reflect through actions like the learning, power or democratise and require a special attention at the design phase and reflection practice (Herr and Anderson, 2005).

This social science requires abilities linked to solve practical problems and improve practice, analytical and reflexive thinking (Levin, 2008). The Action Researcher will have abilities to begin and support involvement in the action and present capability of critical reflection of process and action commitment outcomes. I have noticed that I need to acquire abilities for concrete and practical work. I want to have abilities which make feasible the creation of the sustainable and cogenerative learning process involving participants and researchers at the same cycle of learning. Urgently, I must begin the process of collaborating with the teachers and heritage managers in learning this process and thinking about it critically.

Action Research is an epistemology for knowing and transforming a social reality. We are immersed in the Social Sciences field where practice in the core of the Social Sciences is almost completely ignored (Levin, 2008). I understand practice as collectively construction (Kemmis, 2008). Then practice must be understood not solely from the perspective of the single involved, but also in terms of the collective understandings and collective effects of those involved and affected by the practice. I understand the practice from a dialectically view as Kemmis and McTaggart proposed, pointing out that to understand practice dialectically is to attempt to understand practices in terms of the mutual-constitution, tension and connections between the outside/inside and observer/participant perspective (Kemmis, 2008).

Practice is fundamental to see how certain theory will flourish while people make successive and continuative actions and reflections for facing up a real life situation within a concrete social and cultural context. As theory provides a valuable interpretation of practices, practice itself serves to reshape our theories (Raelin and Coghlan, 2006). 


\section{Acknowledgments}

I am very grateful for the opportunity that Prof. Hilary Bradbury has offered me. Thanks very much for welcoming the action research project proposal, the guided learning process in Action Research and the valuable comments on assignments along three months (July-September 2008).

This research project is relying on the predoctoral grant of IN3-UOC.

I also very appreciate that "Barakia, cultura i noves technologies" wanted to help with the creation and maintenance of the virtual platform.

Finally, I also wish to thank Daniela Matielo for her review. 


\section{Bibliographic references}

ADSIT, M; BARGER, C.; HELAL, D.; ROYAL, J. Learning@Whitney: Developing a useful teaching tool [en línea]. In J. Trant and D. Bearman (eds). Museums and the Web 2007: Proceedings. Toronto: Archives \& Museum Informatics, published March 31, 2007 at [Consulta: 12 de març 2008]. <http://www.archimuse.com/mw2007/papers/adsit/adsit.html>

ALDEROQUI, S.S; ALDEROQUI H (1996). Museos y escuelas. Socios para educar. Buenos Aires [etc.]: Paidós

Arts facts...Improved Academic Performance. [en línea]. American for Arts, 2000 [Consulta: 28 de febrer 2008] <http://www.artsusa.org/pdf/get_involved/advocacy/research/2007/artseducation.pdf>

ASENSIO, M.: POL, E (2002). Nuevos escenarios en educación: aprendizaje informal sobre el patrimonio, los museos y la ciudad. Buenos Aires: Ed. Aique

BAL, Roland; MASTBOOM, Femke (2007). "Engaging with Technologies in Practice: Traveling the Northwest Passage". Science as Culture, 16:3, 253-266

BAMFORD, Anne (2006). The Wow Factor. Global research compendium on the impact of the arts in education. Münster: Waxmann

BRADBURY, Hilary (2006). Action Research: A Survival Guide. Created for fellow executive management students. Cleveland

BRADBURY, Hilary (2001). Learning with the natural step: Action Research to promote conversation for sustainable development. Handbook of Action Research. Participative inquiry and practice. London: Sage

BRADBURY, Hilary; MIRVIS Phil, NEILSON Eric; PASMORE, William (2008). Action research at work: Creating the future following the path from Lewin. Handbook of Action Research.

Participative inquiry and practice. London: Sage

BRADBURY, Hilary; REASON, Peter (2003). Action Research. "An Opportunity for Revitalizing Research purpose and practices". Qualitative Social Work, 2; 155-175

BRADBURY, Hilary; REASON, Peter (2008). Introduction. Handbook of Action Research. Participative inquiry and practice. London: Sage

BRADBURY, Hilary; REASON, Peter (2001). Conclusion Broadening the Brandwitdth of validity: Five issues and seven choice-point for improving the quality of Action Research. Handbook of Action Research. Participative inquiry and practice. London: Sage

BRYDON-MILLER, Mary; GREENWOOD, Davydd; MAGUIRE, Patricia (2003). "Why Action Research?". Action Research, 1; 9-28

CARUTH, N.; BERNSTEIN, S. Building an On-line Community at the Brooklyn Museum: A Timeline [en línea]. In J. Trant and D. Bearman (eds). Museums and the Web 2007: Proceedings. Toronto: 
Archives \& Museum Informatics, published March 31, 2007 at

[Consulta: 12 de març 2008] <http://www.archimuse.com/mw2007/papers/caruth/caruth.html>

Case by case: Can European teachers find digital learning resources related to national or local curriculum [en línea]. European Schoolnet publication Report of LIFE project, 2006 [Consulta: 22 d'agost 2007] <http://wiki.eun.org/life-

wiki/index.php/Main_Page\#Case_by_case:_Can_European_teachers_find_digital_learning_resour ces_related_to_their_national_curriculum.3F>

CASTELLS, Manuel; CARDOSO, Gustavo (editor) (2006). The Network Society. From the Knowledge to Policy. Washington D. C.: Transatlantic Relation, Washington D. C.

Common European Principles for Teacher Competences and Qualifications [en línia]. [Brussel-les] Education Council and the Commission, 2004 [consulta: 11.12.2007]

<http://ec.europa.eu/education/policies/2010/doc/principles_en.pdf>

Confidentiality Agreements. IPR Helpdesk founded by the European Comisión, 2006.

URL Direction: http://www.ipr-

helpdesk.org/documentos/docsPublicacion/html xml/8 ConfidentialityAgreements\%5B000000020 0 00\%5D.html

COGHLAN, David; SHANI, A.B (2008). Insider Action Research: the dynamics of developing new capabilities. Handbook of Action Research. Participative inquiry and practice. London: Sage

DYMEK, Chris (2008). IT and Action Sensemaking: Making Sense of new Technology. Handbook of Action Research. Participative inquiry and practice. London: Sage

ESTALLELLA, Adolfo; ARDĖVOL, Elisenda (2007). Ética de campo: hacia una ética situada para la investigación etnográfica de internet [online]. Forum Qualitative Sozialforschung / Forum: Qualitative Social Research, 8(3), Art. 2, URL Direction: http://nbn-resolving.de/urn:nbn:de:0114$\underline{\text { fqs070328 }}$

Fahrplan für kulturelle Bildung (Road Map for Arts Education). [en línea]. UNESCO-Weltkonferenz zur kulturellen Bildung: Schaffung kreativer Kapazitäten für das 21. Jahrhundert Lissabon, 6. - 9. März 2006 [Consulta: 27 de febrer 2008].

$<$ http://www.unesco.de/fileadmin/medien/Dokumente/Kultur/Road_Map_dt_ArbeitsUEbersetzung_aus_OE_071409.pdf>

FALK J.; DIERKING, L (2000). Leaning form museums: visitor experience and the making of meaning. Walnut Creek: Altamira Press, cop.

FISCHER, Kath; PHELPS, Renata (2006). "Recipe and performing art? Challenging conventions for writing action research thesis". Action Research, 4; 143-164

FONTAL, O. (2003). La educación patrimonial. Teoría y práctica en el aula, el museo e internet. Gijón: Trea

FOTH, Marcus (2006). "Network Action Research". Action Research, 4; 205-226 
GAYÁ, Patrícia; RESON, Peter; BRADBURY, Hilary (2008). Living Inquiry: Personal, Political and Philosophical Grounding for Action Research Practice. Handbook of Action Research. Participative inquiry and practice. London: Sage

GERGEN, Kenneth J.; GERGEN, Mary, M. (2008). Social construction and research as Action. Handbook of Action Research. Participative inquiry and practice. London: Sage

HARASIM, L.; HILTZ S.R.; TUROFF, M.; TELES L. (2000). Redes de aprendizaje. Guia para la enseñanza y aprendizaje en red. Barcelona: EDIUOC: Gedisa

HEEN, Hanne (2006). "About feelings in action research. An experiment in first-person inquiry". Action Research, 3; 263-278

HEIN, George E. (1998). Learning in the museum. London: Edition Routledge

HERON, John; REASON, Peter (2008). Extending Epistemology within a Co-operative inquiry. Handbook of Action Research. Participative inquiry and practice. London: Sage

HERR, Kathryn; ANDERSON, Gary L. (2005). The Action Research Dissertation. A guide for student and faculty. London: Sage

HOOPER-GREENHILL, E. (1999).The educational role of museum. London: Ed. Eilean HooperGreenhill

HORWITZ, R.; INTERNANN, C. We Are Your Audience [en línea] In J. Trant and D. Bearman (eds). Museums and the Web 2007: Proceedings. Toronto: Archives \& Museum Informatics, published March 31, 2007 at [Consulta: 20 de febrer 2008] <http://www.archimuse.com/mw2007/papers/horwitz/horwitz.html>

HOWES, Andy (2001). "School level action research-creating critical space in school communities". Improving Schools, 4; 43-48

ISON, Ray (2008). System Thinking and Practice for Action Research. Handbook of Action Research. Participative inquiry and practice. London: Sage

IWAZAKI, K.; YASUDA, T.; YOKOI, S.; OKAMOTO, T. The Museum Network and On Demand Systems for School Education Based on XML [en línia]. International Conference on Computers in Education (ICCE'02), IEEE, 2002 [consulta: 12.03.2008]

$<$ http://ieeexplore.ieee.org/iel5/8445/26602/01186119.pdf>

KEMMIS, Stephen (2008). Critical Theory and Participatory Action Research. Handbook of Action Research. Participative inquiry and practice. London: Sage

Keys to imagination ICT in art education. [en línea]. [London]: Arts Council England Report, november 2003 [Consulta: 27 de febrer 2008]

$<$ http://www.drumcroon.org.uk/newmedia/documents/Keys.pdf>

KOWALSKI, Rita; YORK, Lyle; JELINEK, Mariann. (2008)The workplace Stress and Aggression Project: Ways of knowing-Our Rosetta Stone for Practice. Handbook of Action Research.

Participative inquiry and practice. London: Sage 
Learning about Learning [en línia]. [London] Creative Partnership London East and South, 2006 [consulta: 13.05.2007] <http://www.creative-

partnerships.com/content/gdocs/learningaboutlearning.pdf>

LEVIN, Morten. (2008). The Praxis of Educating Action Researcher. Handbook of Action Research. Participative inquiry and practice. London: Sage

LÜSCHER, Lotte S.; LEWIS, Marianne W (2008). "Organizational change and managerial sensemaking: working through paradox". Academy of Management Journal, Vol. 51. No. 2, 221240

MACKEWN, Jenny (2008). Facilitation as Action Research in the moment. Handbook of Action Research. Participative inquiry and practice. London: Sage

MONGE, Peter R.; CONTRACTOR Noshir S. (2003). Theories of communication network. Oxford: Oxford University Press

O'CONNOR, Joseph; SEYMOUR, John (1996). Introducción a la Programación neurolingüística. Barcelona: Ediciones Urano

PEDRÓ, F. El professorat de Catalunya [en línia]. [Barcelona] Fundació Bofill, Informe, gener 2008. [consulta: 03.03.2008] http://www.fbofill.cat/intra/fbofill/documents/Dossier_de_premsa_Professorat.pdf

PEIDONG, Li; LADLAW, Moira (2006). "Collaborative enquiry, action research, and curriculum development in rural china. How can we facilitate a process of educational change?". Action Research, 3; 333-350

RAELIN, Joseph; COGHLAN, David (2006). "Developing Managers as Learners and Researchers: Using Action Learning and Action Research". Journal of Management Education, 30; 670-689

RAVITCH, Sahron; WIRTH, Kathleen (2007). "Developing a pedagogy of opportunity for students and heir teachers". Action Research, 5; 75-91

REASON, Peter; BRADBURY, Hilary (2001). Handbook of Action Research. Participative inquiry and practice. London: Sage, 2001

ROTH, George; BRADBURY, Hilary (2008). Learning History: An Action Research Practice in support of actionable learning. Handbook of Action Research. Participative inquiry and practice. London: Sage

RUDOLPH Jenny W.; TAYLOR, Steven S.; FOLDY Erica G. (2001). Collaborative Off-line Reflection. A way to develop Skill in Action Sciences and Action Inquiry. Handbook of Action Research. Participative inquiry and practice. London: Sage

SAGOR, Richard (2005). The Action research guidebook: a four-step process for educators and school teams. California: Corwin Press, cop. 
SIGALÉS, C.; MOMINÓ, J.M.; MENESES, J. L'escola a la societat xarxa: Internet a l'educació primària i secundària [en línea]. Informe final vol. 1, 2007 [Consulta: 19 de febrer 2008] $<$ http://www.uoc.edu/in3/pic/cat/pdf/pic_escola_volum1.pdf>

SCOTT, John (2000). Social Network Analysis. A Handbook. London: Sage

SPRÜNKER, J. "Museums and Heritage Institutions working in network. The case: Territorial System of Museu Nacional de la Ciència I de la Tècnica de Catalunya" Museums and the Web 2008. Montreal, 9-12 abril 2008

SPRÜNKER, J.; MUNILLA, G. "Contenidos digitales fiables y comunidades educativas virtuales para el aprendizaje". IV Congreso de Educared organizado por Fundación Telefónica. 29 - 31 de octubre 2007, Madrid

TAYLOR S.J.; BOGDAN, R. (1987). Introducción a los métodos cualitativos de investigación. Barcelona: Paidós

WENGER, E. (2001) Comunidades de práctica. Aprendizaje, signifcado e identidad. Barcelona: Paidós

ZUIDERENT-JERAK, Teun and JENSEN, Casper Bruun (2007). "Editorial Introduction: Unpacking "Intervention" in Science and Technology Studies". Science as Culture, 16:3, 227-235

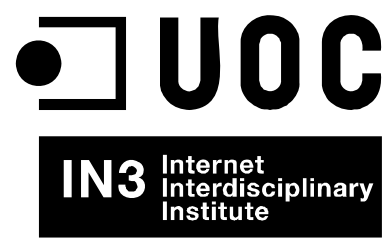

www.uoc.edu 


\section{Annex}

\section{Example of first person research:}

First Action Research is a tool that will help me systematically to think about my own actions and learning. Like Professor Hilary Bradbury has indicated, email isn't fluid. So, I had though that it was relevant to reflect about conversation through CMC. During this project, the majority of communication will be happen by mail, how can I make more efficient this kind of conversation.

There was a heritage institution which was interested in participating in the project, but I had to seek other institution because they didn't pronounce a definite agreement or disagreement. I had analysed a difficult conversation. I made two columns. On the left, I wrote the conversation and on the right column, I did 7 conversational analyses:

- Balance Advocacy \& Inquiry: There isn't a balance between inquiry and advocacy. I didn't look well for a better understanding

- Ladder of Inference: I used more opinion rather than observable data

- Parts of speech: I didn't frame. Professor Hilary Bradbury explained that framing occurs only at the beginning of a conversation in which you clearly state your purpose.

- Conversational roles: It isn't a fluid conversation

- Balance between the columns: The writing in each column is more or less equal. I made seven comments on the right column. I made the left hand column four times more explicit.

- Grade yourself: I evaluated what I said and what I would like had said. I wished twice that I would like to chance sentences. My last two interventions need more transparency between what I was thinking (what I wanted to know) and saying.

- Leverage point for new conversation: I concluded that I had to pronounce more clearly my purpose. I would be able to have introduced more explicitly the time problem and that I needed a formal agreement.

For accomplishing my goals, I will give more transparency in what I want to know and think. In my opinion, a framing should have made more explicit my questions. I couldn't rewrite and resend the emails again, but I can send a mail explaining my decision that has made me to look for another heritage intuition collaborator. 


\section{Members details:}

- Researchers:

Dra. Glòria Munilla Universitat Oberta de Catalunya

Dra. Maria Adela Fargas Peñarrocha Universitat Oberta de Catalunya

Dra. Eulàlia Collelldemont Pujades, Universitat de Vic

Janine Sprünker Universitat Oberta de Catalunya

- Teachers:

Dr. Guillem Vallejo Forés: teacher of Spanish literature and language of IES Mirarmar Francesc Forn Salvà: socials science and history teacher of IES Els Tres Turons José Manuel Rodriguez Calderón: Teacher of history of IES Baix Empordà

- Students (involved in a future phase)

4er ESO IES Mirarmar 1er ESO IES Els Tres Turons

3er ESO IES Baix Empordà

- Heritage managers:

Mireia Forasté Casas: Curator of diffusion of the Museum of Gavà ${ }^{67}$.

Ester Prats Armadans: activity and heritage curator of Roca Umbert, Fàbrica de les Arts ${ }^{68}$. Glòria Gimenez: audiovisual curator of Roca Umbert, Fàbrica de les Arts ${ }^{69}$.

Antoni Rius: content webmanager of Museu Virtual de la Patum

- Webmaster:

Gerald Koegler: Barakia, cultura i noves technologies ${ }^{70}$.

${ }^{67} \mathrm{http} / / / \mathrm{www}$. patrimonigava.com/cat/imgpcn/joc.asp

68 http://www.fabricadelesarts.cat/cat/LlistaEntrevistes.php

69 http://www.fabricadelesarts.cat/cat/LlistaEntrevistes.php

70 www.barakia.cat 
3. Fig. 13. Core AR and thesis in Zuber-Skeeritt and Fletcher's schema (2007, p.421)

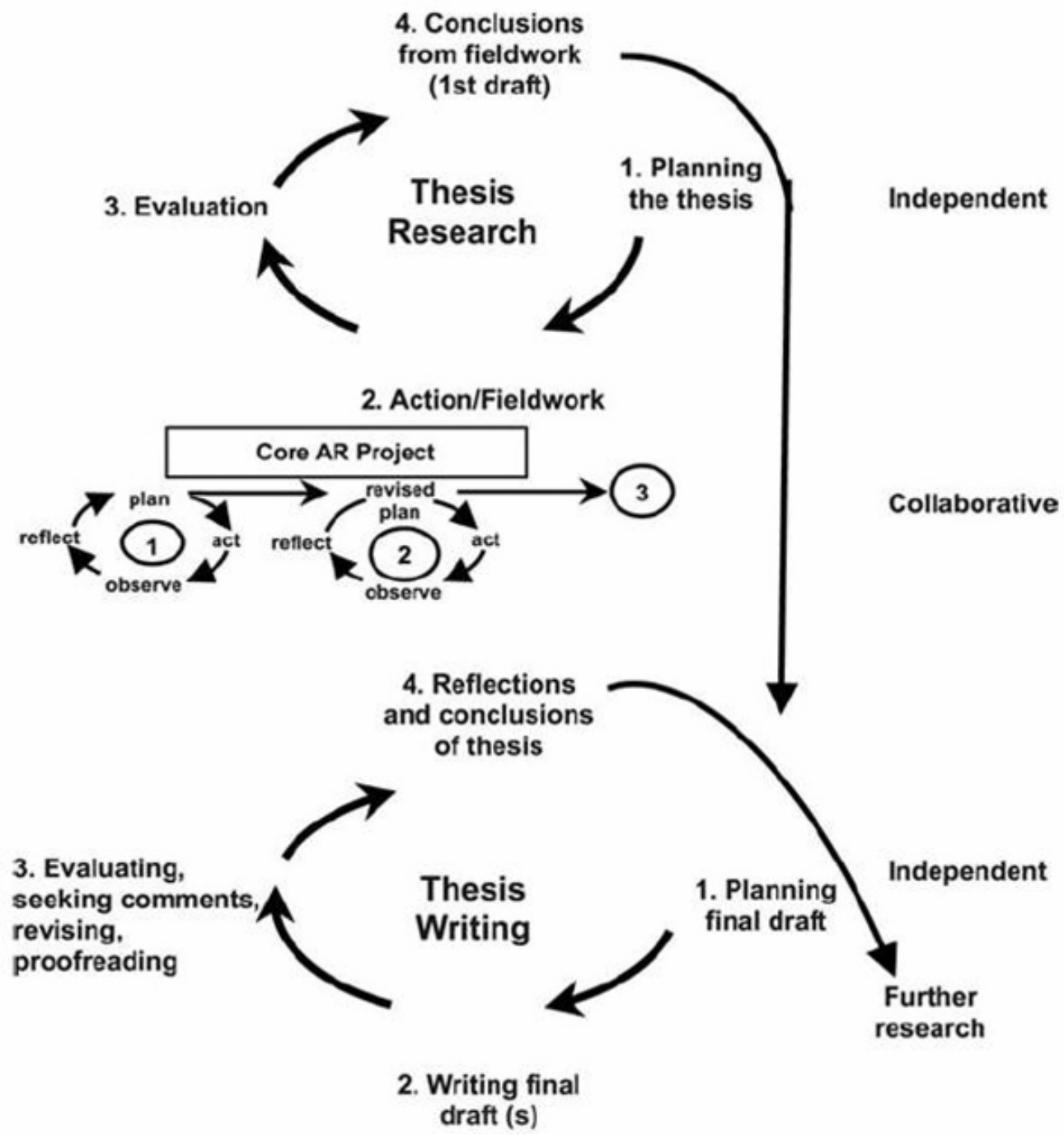

4. Agenda first meeting:

a) Members introduction

b) Project details

c) Presentation of Drupal

d) Activities

e) Questions 


\section{System map:}

Fig. 14. First cycle

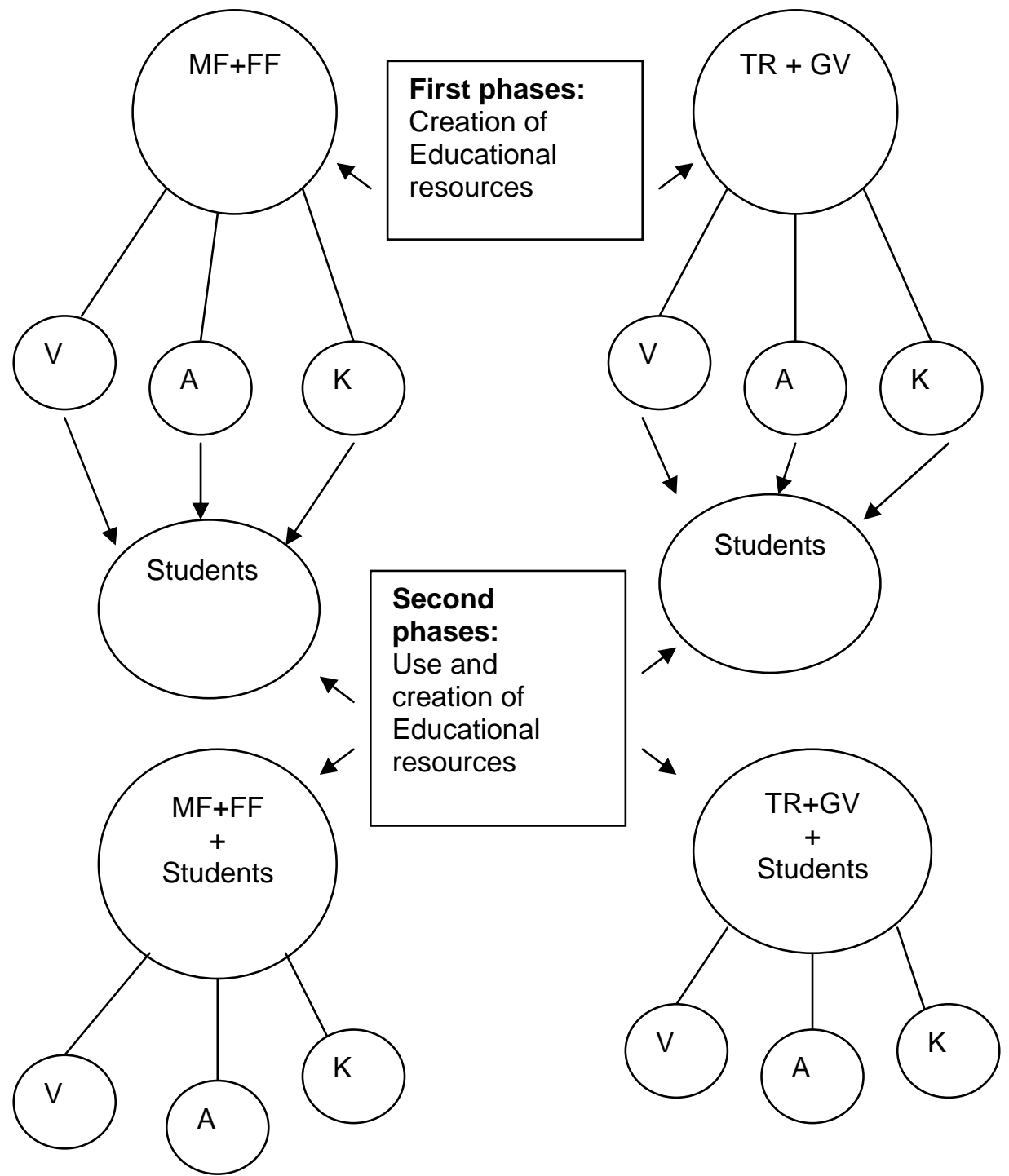


Fig. 15. Second cycle:

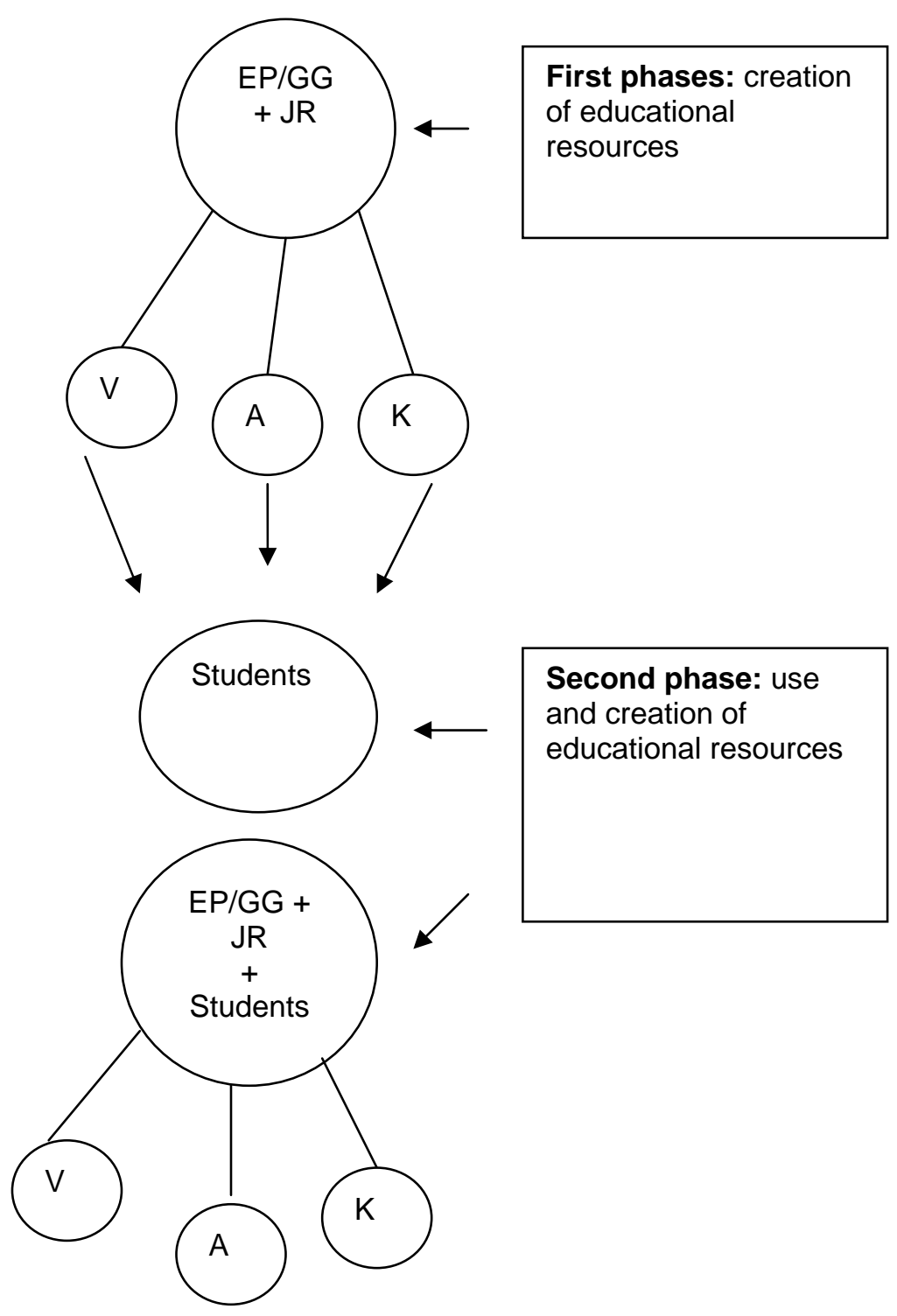




\section{Schedules:}

Fig. 16. Schedule: First cycle: April 08-January 2009

\begin{tabular}{|c|c|c|c|c|c|c|c|c|c|c|}
\hline 2008/09 & April & May & June & July & Aug. & Sept. & Oct. & Nov. & Dec. & Jan. \\
\hline $\begin{array}{l}\text { Establishing a } \\
\text { group }\end{array}$ & & & & & & & & & & \\
\hline $\begin{array}{l}\text { Create virtual } \\
\text { space and tools }\end{array}$ & & & & & & & & & & \\
\hline $\begin{array}{l}\text { Socialization } \\
\text { members, virtual } \\
\text { space and } \\
\text { participative tools }\end{array}$ & & & & & & $\begin{array}{l}\text { First } \\
\text { cycle }\end{array}$ & & & & \\
\hline $\begin{array}{l}\text { Creation of } 3 \\
\text { OERCHC }\end{array}$ & & & & & & & & & & \\
\hline $\begin{array}{l}\text { Socialization } \\
\text { students with } \\
\text { space and tools }\end{array}$ & & & & & & & & & & \\
\hline $\begin{array}{l}\text { Use and creation } \\
\text { of } 3 \\
\text { OERCHC }\end{array}$ & & & & & & & & & & \\
\hline $\begin{array}{l}\text { Collective } \\
\text { reflection }\end{array}$ & & & & & & & & & & \\
\hline $\begin{array}{l}\text { Socialization } \\
\text { members, virtual } \\
\text { space and } \\
\text { participative tools }\end{array}$ & & & & & & & & & & $\begin{array}{l}\text { Second } \\
\text { cycle }\end{array}$ \\
\hline
\end{tabular}

Fig. 17. Schedule: Second cycle: February 09-January 2010

\begin{tabular}{|l|l|l|l|l|l|l|l|l|l|l|l|l|}
\hline \multicolumn{1}{|c|}{$2009 / 10$} & Feb. & March & Apr. & May & June & July & Aug. & Sept. & Oct. & Nov. & Dec. & Jan, \\
\hline $\begin{array}{l}\text { Socialization } \\
\text { members, } \\
\text { virtual space } \\
\text { and } \\
\text { participative } \\
\text { tools }\end{array}$ & $\begin{array}{l}\text { Second } \\
\text { cycle }\end{array}$ & & & & & & & & & & & \\
\hline $\begin{array}{l}\text { Creation of 3 } \\
\text { OERCHC }\end{array}$
\end{tabular}

\footnotetext{
${ }^{71}$ Online educational resources with cultural heritage content

${ }^{72}$ Online educational resources with cultural heritage content

${ }^{73}$ Online educational resources with cultural heritage content
} 